E.L.U.A. 2, 1984, págs. $7-59$

\title{
RETÓRICA COMO CIENCIA DE LA EXPRESIVIDAD (PRESUPUESTOS PARA UNA RETÓRICA GENERAL)
}

\author{
ANTONIO GARCIÁA BERRIO \\ (Universidad Autónoma de Madrid)
}

0.1. Con el auge de los estudios neorretóricos desde mediados de los años sesenta (A. Schiaffini, 1962; Christensen, 1967; M. Maccoby, 1973; L. Heilmann, 1978), se ha producido una situación general más próxima casi siempre al desconcierto que a la clarificación en puntos esenciales. Con mucha frecuencia las causas de ese confusionismo arrancan de un deficiente entendimiento de la auténtica dimensión científica de la Retórica, aunque esto pueda quizá escandalizar como afirmación de entrada a algunas personas. A la Retórica se han acercado en los últimos decenios dos tipos al menos de estudiosos, dotados de formación y de intereses muy distintos. De una parte los investigadores de la tradición clásica, como Lausberg (Lausberg, 1960; Martin, 1974), movidos de una voluntad de reexhumación en todos sus extremos y dimensiones de la ciencia Retórica. Sin embargo, es necesario reconocer que ha faltado, incluso en los mejores casos, como el del propio Lausberg, capacidad o quizá voluntad de integración de esa disciplina perfectamente rescatada en la mayoria de sus enunciados y adecuadamente articulada en sus clasificaciones, en los esquemas de las modernas disciplinas del discurso. Esto resulta a primera vista y sin paliativos escasamente acertado. Ya que la Lingüistica moderna, pariente muy próxima de la Retórica incluso en la gran variedad de sus vias metodológicas de acceso al fenómeno del lenguaje, ofrece un balance ejemplar, si no perfecto, dentro del desarrollo de las llamadas 
ciencias humanas. Como he aludido ejemplarmente a la obra de Lausberg, debe señalarse para explicar y disculpar en su caso ese defecto del divorcio a que aludo, en primer lugar que, dado el ingente volumen de la investigación misma, podría haber sido distorsivo y prestarse tal vez a la confusión establecer por todo el libro un sistema permanente de paralelos entre los materiales retóricos clásicos y los lingü ísticos contemporáneos. Por otra parte, en el decenio de los cincuenta, cuando Lausberg elaboraba su magna síntesis, el balance de la Lingüistica moderna quizá no hiciera tan imprescindible como hoy el esfuerzo de integración interdisciplinar. Pero este hecho, que en justicia sería ingrato reclamar como defecto a Lausberg, se ha traducido en un evidente mal ejemplo para muchos de sus continuadores.

El sector opuesto de los recientes acercamientos lo constituyen aquellos "scholars» que, procedentes de diversas disciplinas modernas de estudio del discurso, tales como la Lingüistica, la Poética o la Semiología -y en muchos aspectos también los lógicos se han querido mezclar en el empeño-, han entrevisto la posibilidad de una fructífera ayuda de las categorias y los paradigmas analítico-interpretativos de la Retórica en algún momento de expansión o incluso de crisis de sus respectivas disciplinas. Si en este aspecto la iniciativa en sí misma la considero personalmente oportuna y aun imprescindible, no cabe duda, juzgando por los resultados finales, que han abundado más hasta ahora los casos de frivola precipitación. Para muchos de estos casos, denunciados desde sectores muy distintos --entre los más brillantes y representativos (P. Kuentz, 1971: 112-114; Groupe $\mu$ : 1977; y J. Kopperschmidt, 1977) - el concepto de Retórica era poco más que un marco demasiado holgado, donde situar cómodamente unas intuiciones vagamente pragmáticas. Para la mayoría de esos entusiastas, la Retórica, recién descubierta por ellos, sería una especie de mecanismo universal de persuasión, con reglas no demasiado bien definidas, 0 cuando mucho un raquítico sistema de estrategias de diálogo o de argumentación, apenas dictadas por el sentido común de los propios neorretóricos. Obviamente la Retórica como ciencia plurisecular of rece muchos más apoyos reales que esa caricatura, destinada casi siempre a alimentar el afán de notoriedad de un reducido grupo de lingüistas y semiólogos “demasiado» famosos.

Desde la situación criticada, pueden intuirse ya las lineas generales que yo atribuiría a la colaboración actual entre la Retórica y las modernas disciplinas del discurso. En primer lugar, se trata de una colaboración posible y fructífera, a condición de que sea el resultado de una auténtica integración en los términos que se delinearán más adelante (1.3). En segundo lugar es imprescindible cargar a la denominación 
de moda de Retórica o Neorretórica con su genuino balance de principios, categorias y estrategias hermenéuticas en el análisis del discurso, precisamente en los propios términos de sus enormes depósitos doctrinales constituidos por una tradición de pensamiento incesante durante más de veinte siglos, a la que han colaborado algunas de las mentes más lúcidas del pensamiento occidental. En tal sentido, debe sentarse inmediatamente el principio de evidencia de que ninguna de las sintesis de Retórica, ni las más ambiciosas y modernas, ni tampoco ninguna de las antiguas, puede constituirse en balance suficiente y definitivo de la tradición general de la disciplina. La historia de la Retórica, como la de la Poética, es tan rica, y los documentos que las constituyen tan numerosos $y$, pese a las apariencias, tan variados, que el proyecto actual de fundar científicamente una reimplantación de la Retórica en el centro de las disciplinas del discurso supone previamente la etapa de una adecuada recuperación del pensamiento histórico. Sólo asi esta iniciativa actual no será frustrada una vez más por irresponsables aventuras en la Poética y la Semiologia.

Precisamente en esa via de integración que vengo definiendo, cobraría pleno sentido el proyecto de la tan acariciada Retórica general. El mérito más indiscutible del grupo de Dubois y colaboradores es el respeto y prudencia con que han tratado de organizar la doctrina clásica francesa sobre los tropos, de Fontanier y Du Marsais, desde un conjunto de categorias elementales, acordes con las líneas de taxonomía categorial y de genética de los sistemas, familiares en la mayoría de los desarrollos estructuralistas. Claro está que, como los mismos participantes del Grupo $\mu$ reconocen, su retórica de las figuras dista mucho de ser una Retórica general; posee, aunque quizá demasiado elementalizada, la voluntad integrativa, pero es obvio que de su proyecto de elocutio ha estado siempre ausente abordar la casi totalidad de doctrinas de dispositio, inventio y actio, que configuraron la Retórica clásica como el más completo instrumento científico de análisis, interpretación y práctica del discurso.

Una auténtica Retórica general, tal como desde la reinserción hermenéutica la entrevió Habermas (1971: 123), o como viene reclamando con energía Kopperschmidt (1977: 216), no puede escamotear sus complejas relaciones con la Dialéctica. Como afirmación de principio, la profundización de la inventio, investigando en sus ya bastantes diezmados o desdibujados orígenes doctrinales griegos, constituye uno de los débitos más urgentes de las especulaciones retórico-cientificas actuales con la poderosa técnica de la elaboración de los productos del discurso humano que fue en origen la Retórica. Pero hecha esta proclamación, no me parece realista sencillamente pensar que exista hoy 
la posibilidad de bucear económicamente en las remotas e inciertas profundidades que en la elaboración de la ideologia cultural griega configuraban ese difícil límite retórico-dialéctico. En todo caso creo que no puede tildarse de parcelamiento caprichoso al prudente deslinde de esas zonas que en nuestros dias pudieron practicar lingüistas y poetólogos, dejando la especulación correspondiente - con las investigaciones histórico-textuales pertinentes- a cargo de lógicos y filósofos de las Ciencias (M. Perelman - L. Olbrechts-Tyteca, 1958; Gadamer, 1965). Es un hecho, por lo demás, que cualquiera que fuese la amplitud de su estatuto fundacional, la Retórica salió ya de Grecia convertida sobre todo en un arte de la persuasión verbal (M. L. Clarke, 1957; Kennedy, 1972; García Berrio, 1977-80). En consecuencia, si la pretensión actual de una Retórica general no debe practicar, sin caer en contrasentido, deslinde ni exclusión alguna respecto de los poderes y cometidos más ambiciosos que puedan haber correspondido a la disciplina en cualquiera de sus momentos de desarrollo, sea en su inserción con la Dialéctica o en cualquier otro aspecto; no obstante, me parece perfectamente licito y realista plantear monográficamente una Retórica general como ciencia del discurso, destinada a integrarse en una Lingüistica general.

Las tareas de esa Retórica general no deben excluir ninguna de las que señale la totalidad de sus apartados tradicionales. Es sabido que la difusión neorretórica reciente se ha visto reducida en la práctica al auge de una Retórica literaria (W. C. Booth, 1965). El mismo Lausberg no veia inconveniente en acoger bajo ese lema específico su tratado y los participantes del Grupo $\mu$ llegan incluso a identificar como sinónimos absolutos función poética y función retórica (Dubois y otros, 1970: 81; R. Lachmann, 1977: 181). Nada cambia los hechos tampoco el carácter oratorio-persuasivo que caracteriza la atención por los estudios de elocuencia en el neorretoricismo americano, quizá la tradición más antigua y vasta que viene a confluir en este reverdecimiento doctrinal (Richards, 1965; E. Black, 1965). Pero una Retórica literaria, que puede llegar a ser un sistema en sí mismo de poderosa complejidad y muy lícito interés, no agota ni con mucho el valor y cometido originales de la Retórica como ciencia o arte de la persuasión; ni puede ser considerada, por tanto, una Retórica general. Esta disciplina ideal por el momento debe extender sus capacidades de aplicación a la inmensa extensión del texto verbal, de cualquier texto con intencionalidad comunicativo-actuativa. El texto literario, o el poético, serán por tanto atendibles dentro del ámbito de esa Retórica general en su condición genérica de textos articulados y enunciados. Pero ningunas circunstancias fortuitas deben invertir la imagen de los hechos. $Y$, sin em- 
bargo, la historia pasada de la disciplina, y la de su reciente reactivación, ilustran muy a las claras que esa inversión se produjo. Una pequeña parte del doctrinal retórico, el tratado de las figuras, especializado por error desde el clasicismo francés icomo Retórica literaria (Fontanier, 1968) -Dubois y sus colaboradores han reconocido inteligentemente este su error de otro tiempo como caso de galocentrismo (Groupe $\mu, 1977$ : 13-14)—, puede conllevar la generalización errónea de que una Retórica general sea, sobre todo, o quizá solamente, una Retórica literaria.

Retórica, pues, o Retórica general se identifican inconfundiblemente con Lingüistica en lo que hace al interés de su objeto común (García Berrio, 1979) más complejo, el texto. En tal sentido además, y precisamente merced al encuentro de intereses de ciertos desarrollos lingüisticos actuales por la construcción global o la génesis semántica del enunciado, a propósito de la Retórica, que habia excedido ya secularmente el interés por la elocutio, contando con el desarrollo muy poderoso en la Antigüedad de la inventio y el auge medieval de la dispositio, no creemos exagerado insistir en la correlación existente entre esa ambiciosa Retórica general, integrada en la Lingüística, y una Lingüistica del texto debidamente desarrollada (Petöfi-Garcia Berrio, 1979; Garcia Berrio, 1979a). En su interés, también lícito e incluso fundamental, por el tipo especial de enunciados verbales que son los de naturaleza literaria o poética, la Retórica general puede especializar, si se quiere, una parcela de interés hacia la Retórica literaria. Lejos de no parecerme interesante, considero este tipo de investigación como el objetivo más importante de nuestras preocupaciones. A él, además, pretendo ceñir monográficamente el contenido de este artículo. No obstante, he creído necesario establecer explícitamente y de modo previo el grado de obligada dependencia de la Retórica literaria a una Retórica general, y no como la afirmación de un principio hipotético, sino como una simple restauración del orden histórico.

0.2. Presupuesta esta organización, y conscientes del orden de dependencias a que nos debemos, el afrontamiento de una Retórica del discurso literario conlleva forzosamente de manera previa, si no por otra cosa en razón del confusionismo que se ha creado desde muchos de los intentos de rehabilitación neorretórica, el examen de su estatuto recíproco con la otra gran ciencia clásica y actual del discurso que es la Poética (B. Lüking, 1977: 52-59). Si los equívocos y deformaciones históricas en el planteamiento actual de la Retórica ya hemos visto que eran notables, no menos entidad presenta en muchos de los casos más 
influyentes y conocidos el confusionismo creado con la Poética. Siempre he juzgado una generalización desafortunada la difusión moderna del término tradicional de Poética (Jakobson, 1958; Todorov, 1968) para designar lo que no pasaria de ser en todo caso sino una Poética lingüística, semiológica, o como quiera llamarse por ese estilo. Tras el auge irresponsable de la generalización hace años - del que nunca he participado, por suerte-, hoy es observable que se procede con mucho más cuidado en bastantes casos (B. Spillner, 1974: 191). Obviamente se trata de una suplantación del todo por la parte. La Poética clásica se constituyó como un conjunto doctrinal, analítico o preceptivo, del texto y el acontecimiento literario, dotado además de un componente no sólo descriptivo - como es el caso de las Poéticas formalistas modernas-, sino también interpretativo en la medida en que atendia de manera muy especial a las causas eficiente y final del acontecimiento literario.

Precisamente lo que la Poética clásica no cubría, o lo hacía insuficientemente - si tenemos que juzgar por las contadas que han llegado a nosotros a partir del maltratado texto de Aristóteles- era propiamente esa dimensión elocutiva del texto de arte verbal. El apartado gramatical de la Poética de Aristóteles no puede cumplir en modo alguno como una reflexión sobre el ornato verbal. Y tanto esta obra como la difundida de Horacio atienden, como es bien sabido, mucho más a los aspectos más generales y abstractos del "decorum» elocutivo que a producir un sistema siquiera sumario de esquemas expresivos (Brink, 1961; García Berrio, 1977-80). Frente a la meticulosa reiteración en los tratados de Poética de tipos estructurales, de fuentes temáticas, de tipologias textuales y aun semánticas de personajes, etc., el tratamiento de la elocución poética propiamente dicho, casilla vacía en los tratados correspondientes, fue paulatinamente cubriéndose desde la Retórica. Es así como la elocutio retórica fue poco a poco haciéndose elocutio literaria (A. Kibedi Varga, 1970: 83), llegando en las retóricas francesas de la degeneración a la completa inversión de los términos, pasando a ser la Retórica un puro inventario de esquemas de exornación verbal, provistos y ordenados por-para-y hacia-las antologías poéticas.

La actual reincorporación de la Retórica a las tareas propias de la Poética debe tener muy en cuenta estos fenómenos del pasado, para no acabar en una lamentable repetición de errores. Bien o mal formada, lo cierto es que existe y está perfectamente disponible esa importantísima y rica casuística de estilística de figuras o esquemas expresivos atesorados por las Retóricas literarias a lo largo de muchos siglos (R. A. Lanhams, 1968). Ninguna de las taxonomías ni de los registros catego- 
riales establecidos por ninguna estilistica no retórica puede brindarnos hoy un sistema más completo para analizar esos auténticos estilemas intencionales que son los efectos de lenguaje denominados figuras. Añádase además que, por lo que respecta a esta cuestión, la integración con el pensamiento actual lingüístico — requisito de una Retórica general- de los esquemas expresivos o figuras es una realidad relativamente estable, ya sea en aspectos concretos, como el pobladísimo ámbito de la metáfora o de la metonimia (M. Le Guern, 1973), ya en el campo de un sistema global, sobre el que supo llamar oportunamente la atención Genette (1966, el trabajo original a que nos referimos se publicó en 1964), despertándose inmediatamente el fugaz interés de Todorov con su temprano y discutido esquema (Todorov, 1967), precedido por la reflexión más madurada de Leech (1966), o los más complejos esfuerzos en este campo de F. Plett (1977), llegando a la meritoria propuesta de la Retórica de figuras del Grupo $\mu$ (Dubois y otros, 1970), cuyo mayor reparo hay que centrarlo no en la cuidada manera de integrar el tratamiento de las figuras, sino en el inconveniente título de la obra como Retórica general (Groupe $\mu$, 1977: 19).

No es poco poder dar por provisionalmente estable y satisfactorio el estado de un aspecto doctrinal como el del tratado de las figuras, desde la perspectiva de constitución de una Retórica literaria, dentro de la Retórica general en curso. En este artículo contaremos ya con ello, como instrumental a punto, perfectamente estabilizado. Pero no pienso que el programa que me propongo delinear en estas páginas deba detenerse en él. Por el contrario, como trataré de señalar en la parte final del artículo (3.1 y ss.), la rigurosa investigación de los materiales de construcción textual depositados en las canteras históricas de la dispositio retórica, y sobre todo la revitalización de la actividad de movere o persuasión a través de una argumentación de valores del emisor, compartida como aceptación de estimaciones por el receptor del discurso artístico, constituyen, entre otros muchos, expedientes decisivos para la revitalización desde la Retórica de una exégesis literaria profundamente escorada en crisis de intereses, precisamente por haber cumplido en su vertiente formal una monumental crisis de superproducción en lo que va de siglo.

A través del enriquecimiento que le aporta la Retórica, mediante la diversificación de sus objetivos más acordes con la complejidad general del objeto literario/poético, la parcelada Poética lingüistica de los últimos setenta años, puede empezar con el advenimiento de la Neorretórica a columbrar las vías posibles de una reimplantación en total justicia de la Poética como ciencia cabal del discurso literario. Y si tenemos presente - y se cumple— la exigencia de integrabilidad en una sintesis 
coherente de todos los discursos científicos sobre el lenguaje, los clásicos y los actuales, puede que incluso sea posible empezar a hablar con razones y esperanzas de una Poética general a partir de la generalización del esquema retórico en todo su alcance.

1.0. Entre las causas del interés que se observa últimamente en diversos sectores de la investigación literaria por la Retórica debe vincularse, desde mi punto de vista, aparte de las de índole general social aludidas más comúnmente ( $F$. Plett, 1977; B. Lüking, 1977: 49-50), la propia situación de profunda crisis metodológica que afecta actualmente a los estudios literarios en Europa. La Retórica literaria viene siendo contemplada por muchos como una perspectiva salvadora ( $R$. Lachmann, 1977: 169-70) del incuestionable amortiguamiento en resultados sorprendentes y espectaculares que está marcando negativamente las diferentes disciplinas que se ocupan del análisis del texto literario (J. M. Klinkenberg, 1977: 80). Adelantaré mi opinión de que, efectivamente, el arsenal de categorias y estrategias hermenéuticas sobre el texto de que dispone la Retórica, puede contribuir decisivamente a revitalizar de muy distintas maneras las disciplinas lingüísticas y poetológicas que se ocupan del texto en general, y singularmente del texto artístico en concreto. Esos diversos modos o niveles de colaboración a que me he referido antes pueden ser catalogados tentativamente según una gradatoria de expectativas de quienes procuran la inserción de los inventarios retóricos en el marco de las disciplinas de investigación textual-literaria:

a) Reimplantación simple y directa de la Retórica. Se trataría en realidad de una sustitución de los diferentes algoritmos analíticos e inventarios categoriales aportados por la Poética semiológica moderna de cuño formal a lo largo de nuestro siglo, desde el formalismo ruso a los neoformalismos estructuralistas (Black, 1965; Ueding, 1976).

b) Complementación y perfeccionamiento. La Retórica se presenta bajo este entendimiento como una rica cantera de materiales destinados a llenar las casillas vacias de la analítica formalista del texto (Groupe $\mu, 1977$ ).

c) Integración interdisciplinar. Bajo esta perspectiva se supondría una actividad de intima colaboración entre Retórica y Poética lingüística, tendente a la reorganización definitiva de los estudios sobre el texto literario, restaurando el viejo tronco doctrinal de la Retórica clásica, articulada racionalmente con las clarificaciones puntuales de la Poética y Lingüística actuales. Tal opción la contemplamos como la vía de una Retórica general viable. 
A continuación examinaremos con mayor detalle las peculiaridades que se presentan con cada una de estas tres opciones, siempre a la luz de la situación de crisis generalizada de los métodos críticos, que establecíamos como marco y punto de partida.

1.1. La reimplantación de la Retórica como recuperación pura y simple de su estatuto hermenéutico-textual en el pasado es la opción de las corrientes de opinión más tradicionalmente reticentes contra los éxitos más recientes de la Poética lingüística. No faltan estos intentos, más o menos encubiertos en nuestros días, en especial en los sectores más conservaduristas de la Romanistica europea, de la Filología clásica y de la «Explication de textes». A la existencia de centenares de tratados sistemáticos de Retórica entre los siglos XV y XIX en todos los países europeos, que podrían ofrecer por sí mismos ya una base sistematizada de uso inmediato, es preciso añadir la importante aportación de síntesis sistemáticas tan difundidas en los últimos decenios como la famosa de Lausberg. Sin embargo, no parece demasiado necesario que debamos esforzarnos por objetar las ventajas de esta iniciativa, ya a simple vista extremosa (Ueding, 1976). Aquí entran en nuestra consideración tanto el concepto de crisis actual de la Crítica literaria como el del fracaso y anquilosamiento en el pasado de la Retórica tradicional.

Efectivamente, la misma Retórica que hoy podría ofrecerse como prometedora fracasó históricamente, en especial a partir del Romanticismo europeo, como ciencia habitual del análisis del discurso ( $R$. Barthes, 1970; Genette, 1968). A ese fracaso concurrió, en un análisis posible desde el presente, un conjunto de causas, cuya incidencia invalidante no habría desaparecido aun hoy. Considerariamos las siguientes:

a) Amortización escolar de las enseñanzas retóricas. Crecientemente, y sobre todo desde las Retóricas tardías del Barroco y Neoclasicismo, la Retórica perdió su carácter no sólo de disciplina interpretativa del discurso, sino incluso como "corpus» normativo de recursos de la síntesis textual. Este proceso de degeneración utópica se intensificaria definitivamente en toda Europa durante el siglo XIX (J. Dubois y otros, 1970: 8). La Retórica pasa a ser una disciplina puramente histórica y monumentalista, en la que no se busca la conexión de los inventarios de recursos y figuras, aprendidas de memoria, con la realidad interpretativa del discurso.

b) Desvinculación del discurso contemporáneo. En cierto modo es 
otra faceta de la causa anterior. La conversión didáctica de la Retórica en una pura disciplina histórica, ucrónica, favoreció la inercia en el mantenimiento de los ejemplos, especialmente latinos (Plett, 1977: 125-8). La ausencia de un sistema de ejemplificación nueva, que sometiera a tensión los paradigmas canónicos de la Retórica greco-latina, medieval y renacentista, fue sin duda una de las causas determinantes del anquilosamiento de esos paradigmas, que a la larga se tradujo en un sentimiento de frustración de los mismos y en un desinterés total, en el fondo, de los escolares. Estos no descubrian en su aprendizaje posibilidad alguna de aplicación utilitaria a sus propias necesidades de formación e interpretación de textos de lengua.

c) Superación del paradigma retórico por los nuevos tipos de discurso moderno. Las tensiones románticas, al atentar programáticamente contra el discurso clásico, en léxico, estructuras sintácticas y textuales, figuras, imágenes, etc... crearon ya un primer tipo de textos deliberadamente antirretóricos, o mejor dicho relativamente desviados del texto clásico y por tanto del paradigma retórico establecido «ad hoc" sobre aquel modelo de discurso. Pero el Romanticismo marca sólo el primer paso de la serie de revoluciones anticlásicas a través de las cuales se estructura, lento y tortuoso, un esquema moderno de discurso artístico. Las sucesivas torsiones del lenguaje en las vanguardias literarias, y los fenómenos correspondientes en la evolución de la norma en el discurso lógico-comunicativo práctico, sancionan definitivamente la crisis de la Retórica escolar clasicista, que, al no presentar una evolución doctrinal paralela a la evolución de los recursos efectivos del lenguaje común y artístico de los nuevos tiempos, sufre, por primera vez, un proceso de insuficiencia de categorias doctrinales, canto sobre el plano descriptivo-interpretativo como sobre el normativo. De esta situación, sensible por ejemplo en la inadecuación categorial de la Retórica tradicional que sintieron los formalistas rusos (A. García Berrio, 1973) para explicar las tensiones del lenguaje y el imaginario futuristas, se perfila la primera crisis de la Critica literaria en el primer decenio del siglo $\mathrm{XX}$; precisamente como una crisis de inadecuación entre los nuevos tipos de textos de arte verbal y el arsenal de categorias críticas interpretativas, provistas mayoritariamente por la Retórica de siglos anteriores.

d) Descrédito final de la Retórica como sinónimo de un tipo determinado de discurso ineficaz. Precisamente por la misma especialización de la Retórica didáctica de las escuelas en un solo tipo de figuras y esquemas de dicción -el que representaria los extremos más recar- 
gados y barrocos de hipérbaton, amplificatio, catacresis, cadencias espectaculares de la frasis, etc..., en resumen, los que caracterizarian un tipo de discurso más enfático y antinatural-, la Retórica cayó en descrédito estilístico con ejemplos tan recordados como el de Verlaine (Plett, 1977;9; Dubois y otros, 1970: 8). Un hablar o un estilo retóricos llegaron a ser en casi todos los paises de cultura a principios de siglo sinónimos de un tipo de expresión exagerada, enfática y grotesca (G. Ueding, 1976). De esta condición indeseable del llamado estilo retórico se pasó inadvertidamente al descrédito generalizado e irresponsable, pero muy efectivo y duradero, de toda retórica. Ese símbolo antirretórico caracteriza por ejemplo en España la afirmación de los escritores del primer novecientos, los llamados «noventaiochistas», contra los hombres de la anterior generación, representantes de las tendencias de la prosa y la oratoria del siglo $X I X$. Téngase, sin embargo, en cuenta que éste era sólo un modo de simplificación. Bien puede decirse que nadie escapa a la retórica, o mejor que todo estilo tiene su retórica: el más abrupto como el más cuidado, el ciceroniano como el tacitista o senequista, el asianista como el ático. La Retórica clásica, como su implantación actual, era una completa ciencia de la expresión, o mejor, si se quiere, de la expresividad (E. Black, 1965: 13-16), una verdadera estilística de la intencionalidad comunicativa verbal; en tal caso, resulta evidente que esa gran disciplina, depósito secular del saber clásico sobre el discurso, contaba con recursos y previsiones para cubrir cualquier modalidad del discurso posible, ya que, en efecto, todas se dieron en el transcurso de los siglos en la comunicación de los hombres. Se puede decir, por tanto, que existe una retórica de la izquierda como una de la derecha política, del liberalismo como del autoritarismo, una retórica de la piedad eclesiástica como de la impiedad agnóstica, etc.

Si esa teoria retórica que ya fracasó, en tales términos, es la que se quiere implantar en nuestros dias idénticamente como alternativa del formalismo crítico, resulta claro que la persistencia actual de las circunstancias y tendencias muy análogas, incluso intensificadas, a las que determinaron su inadecuación pasada, auguran un fracaso idéntico en el presente. Pero es que, además, la naturaleza y alcance de la actual crisis critica, o si se quiere crisis del formalismo crítico, pese a ser evidente, tampoco legitimaria una alternativa tan abrupta. La crisis del formalismo es una realidad anunciada explícitamente por muchos de sus más preclaros cultivadores. Yo mismo, que he contribuido asiduamente durante más de veinte años a la consolidación y a la sintesis de una Poética lingüistica, de base formal, estructuralista y textual, lo proclamo abiertamente sin ningún género de dudas ni de reservas. 
Tácitamente la evolución, un tanto divagante, en sus últimos libros de algunas de las figuras más conocidas del neoformalismo estructural viene a confirmar esa misma sensación general de rumbos divididos, de la hasta hace poco relativamente homogénea orientación textualestructuralista de la critica formal.

Evidentemente, los errores cometidos han sido numerosos, sobre todo en punto a los abusos sobre el texto literario y su lector legítimo. Una metalengua cerradamente canónica y un énfasis excesivo en pruritos de formalización han desorientado a muchos trabajos sobre el texto artístico, que han pretendido atribuirse, consciente 0 inconscientemente, un estatuto inadecuado de lectura crítica de la obra literaria, con una metalengua y unas estrategias de representación del textoobjeto absolutamente ajenas e incompatibles con la inabdicable condición mediadora del discurso crítico, entre el texto -o el autor del texto en el texto- y sus lectores naturales y legítimos. El defecto no es nuevo, como ya señalé yo hace años sin que hasta ahora haya visto desvanecerse mis temores (Garcia Berrio, 1977: 194-6). Creo, sin embargo, que el problema es en el fondo una simple cuestión de pretensiones inadecuadas. Muchos de los trabajos que, por los defectos e inadecuaciones antedichas, no encuentran legitimación a sus pretensiones como ejercicios de critica literaria son sin embargo excelentes sustentos lingüísticos de ejercicios críticos posibles a partir de ellos. En cuanto discursos de Lingüística, o de Poética lingüística o semiológica, los complejos análisis narratológicos, como la mayoría de mis propios escritos sobre tipología textual de la lírica clásica (Garcia Berrio, 1979, 1979c, 1980, 1980a, 1981) u otros muchos semejantes pueden ser perfectamente legítimos. Sin embargo, resultaria ya mucho más discutible la adecuación de tales sistemas formalizados, igual que otros más inequivocamente lingü ísticos como el de J. S. Petöfi (Petöfi-García Berrio, 1979), si trataran de proponerse -que no es el caso en ninguno de estos últimos ejemplos - como modelos de discurso crítico; aunque ocasionalmente puedan haberse fijado como texto-objeto a interpretar o describir un texto literario.

Hechas, sin embargo, las salvedades anteriores, no cabe duda tampoco de que el concepto, a nuestro juicio evidente, de crisis actual de la critica no resulta incompatible con el de satisfactorio nivel de logros de la crítica formal en lo que va de siglo. Las crisis pueden ser de muy variada indole, y la que en la actualidad alcanza a la crítica formal es a mi juicio una crisis de superproducción, de acumulación de innegables aportaciones y aciertos, cuyo único riesgo actual es el de superar lo tolerable en relación a la naturaleza de su objeto. En efecto, si el vacío fundacional de la experiencia critica en los niveles de la forma pudo 
legitimar desde principios de siglo las sucesivas levas de escuelas y analistas literarios formales, es la riqueza misma con la que se ha llenado ese vacio, frente al carácter débil a la hora presente de otro tipo de discursos críticos en torno a la condición estético-social, social-lingüistica e imaginaria del objeto, la que aconseja acudir a esas otras zonas de vacio. Adviértase además que, al menos yo, no contemplo ese desplazamiento de intereses como un abandono simple con olvido de lo ya consolidado en la experiencia de las aportaciones formalistas. Muy at contrario, estoy persuadido de que tales experiencias servirán para orientar el difícil acceso a las nuevas tareas, por vía de proyección. Precisamente desde Bachtin, si no por otros testimonios que pudiesen resultar más sospechosos, nos consta la condición isomórfica del texto literario en el impracticable deslinde real de la forma y el contenido, distentidos entre los tres componentes del constructo teórico: de representación, ético y estético (Bachtin, 1978: 51-52). Por eso me parece que abordar la elucidación de las relativamente vírgenes y fascinantes perspectivas complementarias del objeto literario no puede hacerse razonablemente sino desde la experiencia del perfecto análisisinterpretación del componente formal-composicional del texto; a 10 que me atrevería a añadir, como sugestión verosimil, mi hipótesis de proceder según la proyección de las líneas consolidadas en la experiencia formal-analítica hacia las nuevas zonas ignotas de curiosidad en la constitución integral del texto.

En tal situación resulta, a mi juicio, evidente que la presunta sustituibilidad total del análisis textual formal por el análisis retórico no se puede basar, razonablemente, en la sospecha de una crisis, que en efecto existe; pero que no se funda en la condición insatisfactoria de la Poética formal en sí misma, sino en la necesidad de corregir su desproporcionado desajuste en relación al objeto complejo, el texto literario - como texto y como acontecimiento- que se ha de fijar una Poética sin adjetivos; es decir una analítica interpretativa integral del texto. En el mejor de los casos, la Retórica que se nos ofrece como recambio de la Poética formal bajo este tipo de presupuestos es simplemente la recortada hermenéutica de la elocutio, despabilada cuando mucho en ciertos perfiles de la dispositio sólo en virtud del contagioso ejemplo del interés textual de la narratología estructuralista y de la lingüistica del texto. Es decir, sobre poco más o menos, la nueva parcelada disciplina, cuya necesaria sustitución dio pie a la inauguración de las productivas poéticas formalistas. Y no sería cuestión de recaer en la acusación central de Bachtin de que tales poéticas no alcanzan sino a la elucidación del material en la obra de arte verbal. No otra empresa, y ni siquiera seguramente tan bien como los viejos formalismos, podria lle- 
gar a cumplir esa Retórica que no se ha replanteado en profundidad las posibilidades de iluminación temático-estética desde la inventio, y que quizás nunca llegó a explicar la actio como decisiva posibilidad de orientación pragmática. Una Retórica de tales alcances no se comienza a reconocer sino en la etapa que llamaba antes de complementación, y creo que no se plenifica sino a través del momento final, de integración, dentro del esquema de despliegue en la relación de la Retórica con los algoritmos ideales de análisis-interpretación del texto, que vengo desarrollando en este artículo.

1.2. Descartada la conveniencia de proponer la sustitución total del sistema de análisis formal de textos literarios por el sistema tradicional retórico, se ofrece la alternativa de tratar de completar reciprocamente ambos sistemas. El criterio en este caso, cuya adopción me parece prioritaria, es que en esas operaciones de colación uno de los dos sistemas se constituye en base determinante y el otro en fuente de complementación (D. Breuer, 1974; 1977: 29-30). Por las razones antes aportadas -en especial por (1.1.c)—, referentes al fracaso del sistema retórico tradicional ante las nuevas modalidades de discursos de vocación anticlásica, me parecería más oportuno -y creo que con ello no me opongo además al sentido más autorizado del debate en la bibliografía moderna (Lüking, 1977: 55-59)- que el "corpus» doctrinal de la moderna Poética lingüistica se constituya en base determinante, completándose en sus limitaciones con los amplios inventarios de categorias y de estrategias hermenéuticas que pone a disposición la Retórica (Spillner, 1977: 102). En ese trabajo de complementación pueden darse dos supuestos fundamentales y contrarios:

a) Situaciones puntuales de deficiencia de la Retórica.

b) Situaciones puntuales de deficiencia de la Poética lingüistica.

A continuación atenderemos más en detalle los dos casos anteriores:

a) Existen indudablemente aspectos en los que la Poética lingüistica ha sobrepasado a la Retórica tradicional en punto a explicitud e idoneidad de sus planteamientos sobre la naturaleza del texto objeto. Quizá el más sobresaliente en este caso sea el de las reflexiones sobre la prosa de ficción, y el estilo narrativo en general (Groupe $\mu, 1977: 30$ y ss.). Si se piensa en las razones de urgencia que los formalistas rusos invocaban para legitimar su programa crítico inconformista, se advierte 
la ausencia total de instrumentos analítico-interpretativos de la tradición crítica, fundamentalmente nutrida en cuanto tal por la Retórica, para el análisis de los textos narrativos. Bien entendido que aquí nos referimos simplemente a la narratividad más estricta, no a un vacio doctrinal retórico de categorías y principios relativos a otras modalidades de la prosa artística. Por el contrario, las distintas organizaciones ritmicas que podrían alternar en la organización del "periodare" de la cláusula, o los más amplios esquemas sobre la dispositio de los textos argumentativos, como las distintas modalidades del discurso forense, religioso (artes concionandi), o incluso de la argumentación epistolar (artes dictaminis) (Baldwin, 1928: 206-257; Murphy, 1974: 194 y ss.), junto a muchas otras precisiones concretas sobre la estructura de la prosa artística, estaban ya perfectamente previstas en la Retórica clásica (M. C. Clarke, 1953). Precisamente esas canteras de materiales retóricos sobre innumerables variantes textuales de disposición o estructura de la "causa", el sermón o la carta, constituyen a mi juicio una de las fuentes más sólidas para la Poética estructural y la Lingüistica medieval que puede ofrecer la Retórica, incluso desde la propia Edad Media (E. Faral, 1971).

La cuestión con la que ejemplificamos este apartado, la narratividad, induce un segundo tipo de consideraciones. El tratamiento de la narratividad y de sus estructuras textuales, si constituyen efectivamente un vacio en la tradición de la Retórica, no lo eran en el mismo grado dentro de la Poética tradicional. La relativa modernidad del género narrativo novelesco, coincidiendo en buena parte con la decadencia de la Poética y la Retórica clasicistas a partir del siglo XVII, determina seguramente el vacío analítico y preceptivo de la Poética y la Retórica (Weinberg, 1961: 954 y ss.; 1970-73; Spingarn, 1908: 116-119). Incluso hay que advertir que muchas oportunidades se habian perdido tras de un período de discusiones de más de dos siglos sobre la licitud de este género de textos, precisamente por su condición "no reglada" (B. Hataway, 1962: 87-117). Sin embargo, la narratividad, como modalidad de discurso, contaba con una predominante atención en la Poética clásica desde la misma obra fundacional de Aristóteles, a través de su atención a la sucesividad de acontecimientos presentados por la tragedia. Buena prueba de ello podría ser que algunas de las más popularizadas caracterizaciones sobre estructuras de la narración en la Narratologia reciente, como las nociones de procesos de mejora y empeoramiento procesuales (Bremond, 1966), u otros aún más generales, como la estructura básica de la distribución actancial en el discurso general y narrativo (Greimas, 1966, 1970, 1972), cuentan con más que obvias correspondencias en las descripciones del funcionamiento textual de «fa- 
bula" y “mores», respectivamente, en la tragedia clásica (Vera Luján, 1977). No obstante, el problema general del papel de la Poética clásica en la pretensión actual de la reimplantación de la Retórica como modelo critico merece una consideración aparte, que abordamos en otro lugar de este artículo.

b) Sin embargo, las indudables ventajas de la Poética actual frente a la clásica en la investigación de la dispositio narrativa, a que acabamos de referirnos en el apartado anterior, no constituyen un hecho demasiado generalizable a otros tipos de textos, como los líricos poéti$\cos$, o incluso frente al texto dramático en cuanto a los datos mismos de dramaticidad. Por lo demás, la superioridad de la Retórica clásica resulta absoluta sobre la crítica moderna, incluso sin el concurso de la Poética, en la previsión de las infinitas figuras y esquemas del dominio de la e/ocutio. En este campo las corrientes estructurales neoformalistas han abandonado casi totalmente las líneas globales trazadas por la analítica de los formalistas rusos, en punto a nociones como las de «zaúm» o transracionalidad, conflictos entre sintaxis lógica y rítmica, dinamización textual del elemento aislado, polisentido, etc... Las nociones correspondientes de redes isotópicas (Greimas, 1966: 71; F. Rastier, 1972; Groupe $\mu$, 1977: 30-73) o de redes temáticas (Petöfi, 1973, 1975) constituyen sólo algunas de las escasas posibilidades adecuadamente desarrolladas, frente a la enorme riqueza de las posibles (Klinkenberg, 1973). Quizá este vacío neoformalista lo compensó adecuadamente la tradición de la Estilística, que llegó a crear una sistemática bastante satisfactoria de estilemas elocutivos y dispositivos especialmente poéticos, pero vinculados casi exclusivamente al dominio sintagmático-sentencial, es decir, ceñidos al microtexto (A. Alonso, 1969; D. Alonso, 1952). Y en ello, además, la Estilística española, alemana y francesa era claramente continuadora de la tradición analítica retórica (B. Spillner, 1974).

En conclusión, no cabe duda de que la superioridad doctrinal de la Retórica clásica sobre la Poética formal moderna resulta abrumadora en datos y cuestiones puntuales y concretas. Este balance, sin embargo, no debe resultar, ni mucho menos, escandaloso para una ideologia nutrida en el convencimiento de la superioridad moderna y de la condición de progresivo perfeccionamiento del pensamiento humano. Precisamente lo que causó en su momento la quiebra, y es razón de esa recesión, ha sido la deliberada interrupción del curso evolutivo de la ciencia crítica textual como tradición retórica, operada desde finales del pasado siglo por los diferentes formalismos. Esa ruptura, como tal, 
que no ha llegado en realidad a consumarse, ha dotado en verdad a los postulados críticos de un poder de profundidad esencial que les faltaba en la automatizada analítica de los tratados retóricos (D. C. Bryant, 1967: 36), a costa, sin embargo, de un incuestionable detrimento de categorías analíticas sobre la amplísima extensión global del texto. En fórmula sintética se podría decir que la Poética formal moderna ha incrementado, o al menos ha revitalizado, las capacidades de interpretación textual de la Retórica tradicional, mermando quizá, por abandono y olvido de muchos de los esquemas categoriales de aquélla, sus capacidades de análisis del texto (B. Lüking, 1977: 59).

1.3. Ya decia antes (1.0) que la tercera de las vías de relación entre la Retórica y la Poética lingüística era la de integración interdisciplinar. También adelantaba entonces las ventajas que, a mi juicio, ofrecia esta modalidad frente a las dos anteriores. Téngase en cuenta, a tal respecto, que el principal trabajo de la Poética lingüistica en los últimos ochenta años no ha consistido tanto en innovar aspectos o contenidos inéditos para la Retórica tradicional, cuanto en renovar doctrinas amortiguadas en sus virtualidades analítico-interpretativas del texto, y sobre todo en extender $y$ adaptar tales doctrinas a la doble exigencia de las nuevas modalidades textuales, singularmente de los textos artísticos. Complementariamente ese esfuerzo de adaptación cientifica de la Poética se ha realizado en la voluntad de integrarse y asumir los desarrollos de las demás disciplinas próximas, singularmente de la Lingüistica, en la medida además que el desarrollo de la Lingüística en esos mismos años ha sido ejemplar, y su liderazgo metodológico entre las demás llamadas "ciencias humanas" resulta incuestionable. Así pues, la Poética lingüística ha realizado una importante tarea para dotarse de contenido doctrinal autónomo respecto de la Retórica. Tal forma de proceder de espaldas a la vieja ciencia - creo que después de todo no totalmente ignorándola, pues que eso resulta sólo programáticamente posible - pudo favorecer inicialmente la profundidad y alcances de esa autonomia; sin embargo, en la crisis actual científica de la formalización, puede resultar una alternativa interesante ampliar el número de los objetivos reales a formalizar y a interpretar en el texto. En (1.2) he examinado algunos aspectos de cuál puede ser el sentido de esa ampliación.

Sin embargo, hay que suponer que la relativa crisis de la formalización de las ciencias humanas, que hoy se percibe en numerosos hechos y síntomas, no debe entenderse como fenómeno irreversible y definitivo. Creo, por el contrario, que se trata de una más entre las 
facetas de la crisis de superproducción que afecta a la Poética lingüisti$\mathrm{ca}$, de que partian las consideraciones de este artículo. Esa crisis será tanto más profunda e insuperable, cuanto la Poética lingüistica se resista más a readaptarse a sus nuevos contenidos y exigencias. Una consideración más completa y realista del texto le resulta hoy inabdicable. En tal conceptuación, los aspectos extensionales del texto, su dimensión pragmático-social e individual-estética, reclaman con toda urgencia situar el texto, y más aún el texto artístico, en el auténtico alcance correspondiente a su complejidad y realidad. Es por eso por lo que se registra en estos días la apelación a la complementación retórica, o a la sustitución de la Retórica, que no suponen en el fondo otra cosa que el cumplimiento más obvio e inmediato de esa exigencia de adaptación real a la complejidad del texto, mucho más amplia y general (J. Kopperschmidt, 1977: 217).

Pero por más honda que sea esa crisis actual de la Poética lingüística, y por muy grandes que sean aún las deficiencias y limitaciones de sus objetos de estudio frente a la complejidad real objetiva del texto artístico-verbal, no puede dudarse de la eficacia con que la Poética formal ha cubierto los objetivos que ha abordado, sean éstos pocos o muchos, parciales o totales. La clave fundamental a mi juicio de esa eficacia reside en la profundización de la Lingüistica postsaussureana en sus diferentes modalidades -estructural, funcionalista, generativa y textual- en la naturaleza formal del lenguaje, y en su capacidad de articularlo, a diferencia de la Retórica y la Gramática clásicas, en un entendimiento general de la facultad humana de la producción pensamiento-lenguaje, con una capacidad de evidencia que, cuando menos, se parangona con la de los mejores momentos históricos del pensamiento lógico y gramatical. En virtud de esa asociación, la Poética moderna ha cumplido satisfactoriamente la faceta de sus exigencias fundacionales de revitalizar las categorías retóricas (K. Dockhorn, 1968: 63), rescatándolas de la automatización didáctica a que las habia condenado una larguísima tradición escolar, desentendida de los aspectos reales de producción, análisis e interpretación, desde ellas, de textos productivos de lengua.

2.0. De lo establecido en los parágrafos precedentes se deduce que un programa de colaboración entre Lingüistica y Retórica para elaborar una completa Retórica general sólo podrá ser trazado después de un minucioso examen de la gran mayoría de los textos retóricos existentes, desde su fundación griega hasta su decadencia durante el siglo XIX. Hay que advertir, además, que, aunque la Retórica como 
ciencia haya conocido momentos de auge y de decadencia, todas las edades sin embargo han aportado a sus correspondientes textos retóricos sus propias marcas características, nunca desdeñables. Así, si quizás los textos fundacionales griegos pueden depararnos un interés muy especial en la cuestión capital de límites y colaboración entre Retórica y Dialéctica en el dominio de la inventio (J.E.L. Owen, ed., 1968), y ese interés desaparecería totalmente en los retóricos del Clasicismo francés (Klinkenberg, 1977:80); no es menos cierto que en estos últimos la sistematización y descripción de los «schemata lexeos" o figuras adquirió un grado de riqueza y clarificación que quizás nunca habia alcanzado (Genette, 1968). Sin contar con el hecho inolvidable, sobre el cual no me cansaré de insistir, de que en esta cuestión como en casi todas el cotejo de las canteras de documentación histórica, si se realiza con cultura y empeño adecuados, ofrece invariablemente mejores pautas y materiales a la reflexión contemporánea que cualquier esfuerzo individual de sintesis sistemática, que haya vuelto las espaldas a la búsqueda histórica. Así, sin salir del propio tema de las relaciones con la Dialéctica, aun ya en épocas de poderosa implantación de una Retórica fuertemente elocutiva y literaria, como la Italia de los siglos XV y XVI (C. Vasoli, 1968), o Inglaterra entre 1500 y 1700 (W. S. Howell, 1956 ), cuidadosas revisiones de las fuentes disponibles, como las dos referenciadas, descubren perspectivas inimaginables incluso para cuestiones palpitantes contemporáneas como la lógica de la persuasión o la teoría de la argumentación.

Pero esa tarea de revisión histórica, que además, para no ser puramente inútil y monumentalista, ha de incidir sobre un suelo adecuadamente nutrido en las disciplinas actuales —Lingüistica, Lógica, Semiología, Psicologia, etc...- no es fácil ni cómoda, aunque pueda ser apasionante. De hecho no conozco ni una sola iniciativa, individual o de un equipo, que la haya realizado. Sin embargo, las dificultades no deben oscurecer la urgencia e insustituibilidad del esfuerzo. Permitaseme, una vez más, recurrir al autor más meritorio para ejemplificar un defecto, el Handbuch der literarischen Rhetorik de Lausberg apenas si dedica unas cuantas páginas especificamente tales al tratado de dispositio (Lausberg, 1960: $\S \S 443-452$ ). Por ese procedimiento, además, Lausberg incomunica privilegiadamente su magno esfuerzo con una de las preocupaciones básicas de la Filología moderna, la noción de estructura del texto, clásica desde la Narratología a la actual Psicología cognitiva, pasando por la Lingüística del Texto. Esta es, a no dudarlo, una de las lagunas de más urgente remedio en un proyecto de Retórica general. Esa importante limitación del Handbuch se debe fundamentalmente, no al efecto de ningún tipo de prejuicios o partido previo por 
parte del autor, sino a la peculiaridad de la muestra parcial de fuentes clásicas por él seleccionadas. La dispositio estructural del texto se refugió fundamentalmente desde el Medievo en un tipo de tratados retóricos especiales, las artes concionandi y las artes dictaminis, que Lausberg no tuvo en cuenta. Evidentemente el gran investigador alemán pagaba tributo así al prejuicio de mayor circulación, identificando Retórica literaria exclusivamente con Retórica de las figuras, a diferencia de lo que ha sido el interés de la critica literaria moderna, fundamentalmente estructural-textualista.

2.1. En defecto de esa investigación histórica exhaustiva, puede fijarse no obstante, incluso como programa previo de Retórica general, un balance provisional de problemas desde la conciencia actual de la convergencia entre Retórica y Lingüistica. Tal balance afectaría, en mi opinión, a las siguientes cuestiones capitales dentro de la inventio:

a) Redistribución de los conceptos de contenido y forma (res-verba) entre las tres operaciones retóricas básicas de inventio, dispositio y elocutio. Como es bien sabido la identificación de res con inventio y de verba con elocutio, sin señalar estatuto preciso para la dispositio, fue casi permanente en el entendimiento clásico de las disciplinas del discurso '. La responsabilidad de esta disfunción es máxima en la fisonomía interna de ciencias como la gramática clásica, cada vez menos semántica y textual, y más morfológico-sintagmática, o como la misma Retórica, progresivamente alejada de los problemas dialécticodispositivos, y más concentrada en los elocutivos. No creo exagerado atribuir a este defecto de óptica cientifica sobre la naturaleza del lenguaje quizás el primer lugar en la responsabilidad de los desvarios conceptuales, tanto de la Retórica como de la Lingüistica y la Poética, y en general de todas las disciplinas históricas que se ocupan del discurso. Para subsanarlo considero capital, junto a la investigación puramente retórica en sus puentes de inventio dialéctica y de dispositio textual, profundizar en la investigación actual en el ámbito de la macroestructura (Petöfi, 1975a; van Dijk, 1977), bajo cualquiera de sus vertientes, desde las semiológico-narratológicas o argumentativas (Greimas (ed.), 1972) a las psicológico-cognitivas (van Dijk-Kintsch, 1977; van Dijk (ed.), 1982).

\footnotetext{
1 Obsérvese la perpetuación del defecto en Lausberg, la identificación defectuosa se encuentra en $\S \S 255 ; 444-445$ y 454 .
} 
Desde el punto de vista histórico-retórico, quizás una de las cuestiones más ilustrativas entre las que se refieren a este tipo de problemas sea la de la confusión histórica, estudiada por mí en reiteradas ocasiones, entre un término correspondiente a la inventio retórica, vø $\mu_{\eta}$, como dicho breve de alcance universal cognitivo, y el correspondiente poético, $\delta\llcorner\alpha$ vol $\alpha$, definido por el propio Aristóteles en términos de semiótica connotativa (García Berrio, 1979c: 34-35) como el significado de la $\lambda \varepsilon \xi \xi$, y significante con ella del significado sucesivo (mores/caracteres y personajes) dentro de la estructura general de la

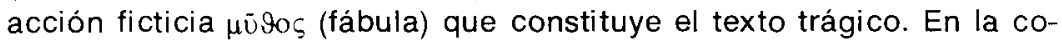
mún traducción latina de ambos términos en uno solo, sententia, se confundieron definitivamente no ya dos conceptos en realidad distintos correspondientes a dos tipos de textos diferentes (discurso-retórico vs. tragedia-poética), sino sobre todo un concepto, el retórico, de alcance

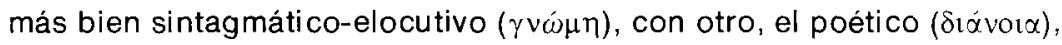
de índole más predominantemente textual-inventiva (Garcia Berrio, 1980b: 3-6). Hechos como este prueban: 1) la sucesiva degradación de la dimensión textual en el pensamiento gramatical frente a su altamente estabilizada responsabilidad en la Poética y la Retórica clásicas; 2) correlativamente, el debilitamiento de la dispositio y de la Poética a costa de la elocutio y la Retórica. Por lo demás, el sintomático ejemplo que he seleccionado no es ni mucho menos irrelevante. La transcendencia histórico-literaria y conceptual-lingüistica de este fenómeno fue decisiva para la implantación secentista del «concetto» barroco, con el correspondiente desplazamiento de la teoría de la metáfora - sustancialmente alojada en la Poética desde Aristóteles- al ámbito definitivo de los «schemata" retóricos, con que se consagraria desde las retóricas del Barroco europeo de Gracián y Tesauro (Mazzeo, 1933; Woods, 1968; F. Monge, 1966; García Berrio, 1968; A. Collard, 1967; K. P. Lange, 1968) hasta los canonizadores de la elocuencia del Clasicismo francés como Du Marsais.

b) Adecuada articulación de la sucesividad teórica en las partes del discurso retórico a la simultaneidad de las operaciones de enunciación verbal. Muy próxima a la inadecuación antes expuesta —en a)-, y no de más leves consecuencias, fue la simplificación habitual en los tratados de Retórica de las cinco partes del discurso-inventio, dispositio, elocutio, memoria y actio- como imagen general de la productividad del acto lingüístico. En esa confusión, la idea de la sucesividad (Lausberg, 1960: § 255) de las partes venía sugerida desde el De Oratore de Cicerón (1. 31, 142) -en uno de los propios ejemplos seleccionados por Lausberg- mediante partículas subordinativo-sucesivas tan expli- 
citas como: «primum quid diceret, deinde inventa non solum sed etiam momento... tum ea denique vestire... oratione, post memoria saepire, ad extremum agere». La generalización de esta enumeración de partes confundía y simplificaba:

1) La doble perspectiva onomasiológica/semasiológica del discurso, situándola desde entonces preferencialmente en la perspectiva exclusiva de la producción; contra el hábito tradicional de la propia Retórica que había tributado su atención paritariamente a la producción y a la recepción, a través de su atención a los efectos persuasivos del discurso (delectare, docere, movere) en cualquiera de los tres géneros básicos. Recuérdense al respecto la existencia de dobletes categoriales en la Retórica antigua tan significativos como inventio/intelligio para representar la doble perspectiva, creativa/receptiva, de una misma actividad de hallazgo conceptual.

2) La existencia de un verdadero plan real de producciónrecepción del discurso, basado en un orden no lineal-sucesivoterminal-fijado (Petöfi, 1973: 221) sino en el principio de la simultaneidad de operaciones, y de la ordenación mediante un sistema de transformaciones macro y microcomponenciales (van Dijk, 1972: 139-56), operante como un bloque de información sobre la base textual (Petöfi, 1975: 8-15; Albaladejo Mayordomo-Garcia Berrio, 1982: 234).

3) El «orden retórico", tanto desde la experiencia de la propia conciencia lingüística y de la elemental competencia, se revela como contradictorio, ya que busca afirmarse como orden planificado del discurso, siendo en realidad una arbitraria desordenación del plan textual.

Dado el grado actual generalizado de conocimientos lingüisticos, no me parece necesario insistir en la realidad y consecuencias históricas y doctrinales precipitadas por un orden de compartimentación cerrada como el impuesto por el estereotipo de la producción retórica (Spillner, 1977: 100-104). Creo mucho más necesario e ilustrativo, por el contrario, extenderme a explicar la génesis histórica de esa generalizada deformación. Quizás así, una vez provista esa aclaración, será perfectamente deslindable el momento en que se pasó históricamente de un convencionalismo doctrinal inocente a una deformación errónea de la realidad, con efectos profundos y muy duraderos. La generalización de la sucesividad puramente expositiva de las partes del discurso a categoría general de explicación se produce con el olvido de las reglas del arte. Téngase en cuenta que las artes - gramaticales, retóricas, poéticas-eran una modalidad muy específica de discurso. Así, por ejemplo, todos los expositores modernos de la Epistola ad Pisones de Horario (O. Brink, 1961; K. Becker, 1963; A. García Berrio, 1977-80) han tenido que partir de la regla de género de ese tipo de epistolas 
literarias, que imponia un determinado modelo de estructura dialogal, desde el cual las reinsistencias doctrinales eran un tipo de imposición decoroso-verosímil en la argumentación perfectamente fijada entre las reglas del género. El redescubrimiento de las condiciones argumentativo-estilísticas de este tipo de tratados alejandrinos y romanos ha permitido valorar en términos de redundancia metateórica y no de simples defectos de exposición las digresiones y circularidades del discurso horaciano.

Análogamente debe tenerse en cuenta para la comprensión de la exposición sucesiva de las partes del discurso en Cicerón o Quintiliano el inolvidable carácter de arte o $\tau \hat{\varepsilon} \chi \nu \eta$ de tales tratados. El convencionalismo didáctico-expositivo venía impuesto por la finalidad didáctica y preceptiva con que se componía y leía este género de discursos. Yo mismo he señalado la incidencia hoy difícilmente concebible, de muy serios propósitos didácticos, individuales y sociales, en el Ars Poetica de Horario (García Berrio, 1977-80, I: 217-221), que parecen contrastar y aun rebajar la autoestimación del mismo gran poeta latino por si mismo y por el significado genial de sus capacidades creativas. La perfecta circulación contemporánea del convencionalismo didáctico del tipo de tratados que impuso la enumeración sucesiva de partes del discurso nos permite conjeturar analógicamente que el estilo de errores a que aquélla indujo fue posterior al momento de su difusión contemporánea. Y por tanto debe conceptuarse como uno más de los casos de perturbaciones o ruidos técnico-ideológicos en la transmisión cultural de las disciplinas del discurso. La conciencia de $\tau \dot{\varepsilon} \chi \vee \eta$ especializada distanciaba la exposición preceptiva de los momentos en la elaboración calculada de una pieza de argumentación forense, de la descripción de cualquier acto comunicativo de habla, siempre relativamente improvisado por mayor que sea su complejidad. El estado doctrinal previo a esa etapa didáctico-especializada de la Retórica como tratadistica de la elocuencia convencional no nos es hoy bien conocido; ni siquiera tenemos constancia de la existencia como tal ciencia de la interpretación/análisis/formación de cualquier tipo de discursos. En Cicerón y Quintiliano, proveedores de materiales para la mayoria de las sintesis modernas de Retórica, ésta era ya claramente una tratadistica especializada de la formación civil y forense, y sólo secundariamente una ciencia del discurso oral en general. Lo que históricamente sucedió fue que la más marcada decadencia o inmadurez relativa de las otras ciencias del discurso respecto de la Retórica llevó a ésta a representar un tipo de responsabilidades en la organización medieval dèl "trivium" inadecuadas en puntos como el que nos ocupa. 
No obstante, y decididamente corregidos los dos tipos de desajustes que he señalado, la enumeración y descripción de partes del discurso popularizada por la Retórica puede ofrecer, y de hecho ha ofrecido, una pauta segura y relativamente exhaustiva para la concepción de los mecanismos de producción del texto (D. Breuer, 1974; especialmente, 1977: 32). En este caso, no ya sólo los desarrollos y aportaciones de la Lingüistica del Texto europea, antes señalados, o del estructuralismo semiológico francés; sino las propias aportaciones del generativismo chomskyano pueden establecer una corroboración y perfeccionamiento culminativo a los datos tradicionales de la Retórica. Cualquiera que sea el grado de concreción y realidad lingüística de conceptos productivos como los de estructura profunda, jerarquía de transformaciones, transformaciones sintáctico-semánticas, inserción léxica, transformación generalizada, optativa y obligatoria, etc..., no cabe duda que perfeccionan, como quizá ningunas otras doctrinas gramaticales hasta el presente, el alcance real y el orden de producción de los componentes del viejo paradigma retórico (Spillner, 1977: 104).

c) En el problema precedente es quizá la modernidad científica la que alcanza el primado e iniciativa frente a la Retórica tradicional en el volumen e interés de las aportaciones respectivas. Pero en otros muchos órdenes de la colaboración, la situación dista notablemente de haber llegado a ese mismo grado razonable de perfeccionamiento actual de las enseñanzas tradicionales. Uno de los casos más importantes y llamativos lo ofrecen las tipologias retóricas - $\mathrm{y}$ en muchos casos las poéticas- de modalidades de discurso. Dentro del dominio retórico de inventio, la misma categoría inicial de los tres géneros: judicial, deliberativo y demostrativo, supone una taxonomía precisamente establecida sobre criterios y límites perfectamente englobados en una visión exhaustiva de las posibilidades del discurso, donde entran las variables fundamentales del interés del emisor, el tipo de receptor, la finalidad a conseguir, la naturaleza del mensaje y sus posibilidades de ubicación respecto del presente del acto de habla, etc... (Lausberg, 1960: §§ 59-65). Frente a una taxonomía dialécticamente tan bien entablada, las tipologias modernas, aun las más esforzadas, pueden incluso parecer relativamente desorganizadas e incompletas (Gülich-Raible, 1972). De hecho son incontrovertibles las desigualdades actualmente existentes que arrojan tipos de discurso perfectamente descritos como el narrativo, frente a otros relativamente inéditos desde el punto de vista lingü ístico. El conocimiento de tipos de discurso como la descripción y la argumentación (A. Naes, 1975; L. K. Jones, 1977), por no hablar del total vacio taxonómico en que cristaliza el interés moderno por el género 
clásico de expresión sintomática-intimista y subjetiva conocida tradicionalmente como lírica, no resulta doctrinalmente proporcionado, en modo alguno, a la decisiva importancia de tales nociones en una descripción lingüística.

Históricamente además la perspectiva de modalidad expresiva adoptada tradicionalmente por la Retórica para sus taxonomias textuales ha evidenciado una capacidad predictiva incomparable respecto al nivel de exhaustividad de cualesquiera otros principios. El caso tipológico de mayor complejidad y transcendencia conocidas entre los tipos textuales de modelos de discurso, que es el de los géneros literarios, puede ilustrar perfectamente esta aseveración. Por ceñirme sólo al caso de los géneros mayores, es bien conocido el carácter tardío de la conciencia dialéctica de un tercer género, la lírica, frente a los otros dos, épico y dramático. Igualmente notorio es que la noción, existente ya en Grecia, carecía del relieve taxonómico dialéctico que alcanzó desde el tardío Cinquecento italiano, sobre todo a partir de L'Arte poetica de Sebastiano Minturno (García Berrio, 1973a: 152-153; 1975: 369378 ). Por más que la existencia histórica de tipos textuales globalmente caracterizables como poesía ditirámbica estaba ya bien afirmada en la literatura de Roma, y sobre todo la realidad temático-estrófica de los varios géneros como canción, soneto, madrigal, etc., resultaba una evidencia total para artistas, lectores e incluso tratadistas de estos géneros temático-estróficos concretos (Weinberg, 1961, 1970-73). Por si algo faltara, desde el propio Dante, estaba ya definitivamente sancionada la peculiaridad estructural de géneros como el soneto, incuestionablemente legitimados frente a las objeciones tradicionales basadas en su presunta carencia de «imitación». Recordemos cómo en el De vulgari eloquentia (II, VIII, 8) se señalaba el "Concetto" como la ufabula" del soneto.

Todo ello, no obstante, no era suficiente para instaurar la definitiva conciencia dialéctica de los tres grandes géneros mayores. La gran novedad de Minturno consistió precisamente en darse cuenta de que del campo cubierto para la modalidad exegemática de expresión, es decir, aquella en la que el emisor "habla por sí mismo» —o lo que es lo mismo, cuando el sujeto de la enunciación coincide con el sujeto del enunciado-, no correspondía con ninguno de los otros dos géneros canónicos, el teatral -trágico y cómico- correspondiente con el dramático, con sujeto de la enunciación distinto del sujeto del enunciado, y el mixto propio de la epopeya, "que es aquel en que el poeta habla unas veces por sí mismo y otras introduce alguien a hablar». Sólo a partir del auxilio de la tripartición retórica de los "genera dicendi" se culminó un proceso consciente de taxonomía histórica de los géneros 
literarios (B. Lüking, 1977: 51), pese a las indudables evidencias ofrecidas por la realidad histórica de la creación artística.

El valor orientativo para la tipologización de clases textuales no decae al afrontar las taxonomías retóricas más profundas y ramificadas. Asi por ejemplo los tipos de quaestio - simplex, coniuncta y comparativa, o la división de las mismas en finita o real e infinita o filosófica- crean evidentes posibilidades de profundización de modalidades de organización textual hasta ahora nunca tenidas en cuenta en los trabajos de clasificación de discursos, que indirectamente contribuyen a profundizar la ciencia misma del texto. Otras pautas de positivo valor, si bien quizá para supuestos de organización textual mucho más circunstanciados y concretos, las ofrecen los tipos de confesión o respuesta, simple (feci), o compuesta o "vestida" (feci sed aliud/feci sed iure), o bien los status, que etimológicamente significaban la postura inicial adoptada en la argumentación: de coniectura o comprobación de los hechos, de definitio o calificación exacta de la figura jurídica, de qualitas o calificación en términos de legalidad/no legalidad, o de translatio, por impugnación de la legalidad.

d) Si la inventio quedaba configurada en la Retórica clásica a la vez como un instrumento dialéctico de descubrir las circunstancias inherentes a la cuestión o tema debatido, según el conocido cuestionario básico de interrogación, y sólo secundariamente como un inventario de conocimientos $y$ hechos pertinentes al saber del retor, fue la aplicación poética de la inventio retórica, o al menos su apartado correspondiente, lo que fijó un cierto tipo restringido de tematismo, apto o decoroso, en correspondencia y apropiación a la verosimilitud del tipo de lenguaje correspondiente a los personajes. La incidencia histórica de esta modalidad de reglas y restricciones de base retórica en la constitución arquetipica y tópica de los textos ha tenido consecuencias de la mayor importancia, destacadas, en contraste, en raras ocasiones por la Lingüistica y la Poética modernas. Además, como señalaremos sucesivamente, en el establecimiento de una tópica del discurso moderno, equivalente a la tópica restrictiva de la inventio retórica del discurso clásico, radicaría quizá una importante tarea todavía inédita de la Psico- y Sociolingüística, así como del Psicoanálisis lingüístico y de la Antropología social. $Y$ si este programa lo planteo con las obligadas restricciones de prudencia, en campos que me son mucho más familiares como el de la Poética y la Literatura, no veo inconveniente en considerar dicha tarea entre las de mayor importancia que esperan, absolutamente virgenes aún, a una Teoría literaria del discurso artístico moderno. 
En este sentido el difundido y acertado concepto de obra abierta (U. Eco, 1962) ha venido asociado con determinadas aseveraciones de Barthes, igualmente brillantes y productivas, sobre la polisemia constitutiva del discurso anticlásico (Barthes, 1972: 41-44) al planteamiento quizá excesivamente aventurado de una cierta antirretórica. Como es bien sabido, por lo demás, ni Barthes, ni sobre todo Eco, enfatizaron tanto la condición abierta del discurso moderno en el plano de la inventio temática, como de la dispositio estructural. Sin entrar por ahora en la discusión en los propios términos exactos de Eco o Barthes, la expansión de la hipótesis antirretórica, polisémica o abierta al dominio de la inventio temática no deja de ser, a mi juicio, una pura hipótesis o "desideratum» con escaso sustento en el análisis de la realidad. La creencia más extendida de la dispersión temática al infinito de la poeticidad, literaridad o esteticidad llamadas "modernas" no deja de ser una pura sospecha sustentada más en la impresión precipitada por las apariencias que en ningún modo de efectivo recuento, o análisis taxonómico, irreductible a estrechas reglas básicas de producción. Si mis propias tipologías temáticas sobre la lírica clásica europea han llegado a probar fehacientemente la condición altamente económica del inventario de unidades y situaciones de base en géneros temáticos de apariencias tan múltiples como el amoroso cortés — con poco más de treinta invariantes temáticos de base (Garcia Berrio, 1979c)-, el satírico-burlesco, o incluso el conmemorativo, no alimento demasiadas dudas sobre que, adecuadamente estudiados y tipologizados, los indiscutibles esfuerzos del artista moderno para establecer un inventario de temas no convencionalizados arrojarian también algunos principios de economia estético-comunicativa que contribuirían a "cerrar" incalculablemente los inventarios de apariencias infinitamente varias.

Posiblemente en los textos más herméticos e irracionales producidos por la poesía moderna desde el futurismo y el surrealismo, como en las variedades temáticas y estructurales de la prosa o la plástica moderna, no haya triunfado tanto, pese a las apariencias más inmediatas, una retórica infinita de la apertura textual temática y estructural, cuanto una anti-retractatio frustrada por la naturaleza de la cosa. Quizá en el arte moderno haya imperado más la negatividad que la productividad efectiva frente al arte clásico, más la oposición que la alternativa. Pero la negación de una retórica funda sólo una retórica del contrario, sin dar origen a una nueva retórica ni garantizar el abandono definitivo de cualquier otra. Quizá prolongando simplemente más allá del punto de convergencia clásico la afirmación estructural como unidad de intención constructiva del texto encontraríamos delineada la regla de la divergencia estructural, abierta, del arte moderno, con otra cono- 
cida y feliz categoría crítica reciente, la interpretación (S. Sontag, 1969) sigue siendo fatalmente inseparable de cualquier entidad artistica moderna, constitutiva de texto y por tanto de afirmación y de sentido. Obviamente la afirmación de una retórica sobre los «topoi» modernos distinta de la clásica, pero análogamente finita y económica, es una aventurada hipótesis; pero la existencia de lineas de continuidad más que evidentes en las modalidades de producción textual, comunicativa y artística, que caracterizan globalmente los espacios culturales conocidos como clásico y moderno -o más exactamente anticlásico-, permite conjeturar con razonable justicia la licitud y productividad de tal hipótesis. En cualquier caso, el establecimiento de una nueva inventio para el tipo de discurso moderno, que corrobore y tipifique la finitud de sus lineas de convergencia en nuestra hipótesis, o que ilustre incontrovertiblemente sobre el paralelismo infinito de las divergencias y su condición no recursiva, constituye incuestionablemente una de las tareas más urgentes de la nueva Retórica, constituida asi, también por la ambición y representatividad de sus objetos de análisis (Lachmann, 1977: 169), en auténtica Retórica general.

2.2. Quizá el grado de mayor atractivo en las expectativas de actualización cientifica de la Retórica lo ofrece la posible reinstauración de esta disciplina como técnica de la persuasión. En este punto coinciden muchas instancias de origen diferente. Inicialmente ha liberado esta tendencia, quizá por la agudeza y la agresividad de su presentación una teoría de la comunicación ideológicamente orientada, como la que preconiza Josef Kopperschmidt (1976: 83-84), que aspira a reimplantar una auténtica Retórica - y no un mero dispositivo "tecnológico", falseado en su especialización literaria-como "gramática de un discurso razonable", a través de un acto comunicativo que rompe estratégicamente la discusión hasta la culminación del consenso entre los protagonistas del acto comunicativo. Sin embargo, no son en el fondo tan distintos como incluso el propio Kopperschmidt los afirma, persuadido desde la urgencia de una ortodoxa teoría de la comunicación retórica, los intentos de todo un gran sector de la Retórica de procedencia y límites filológicos, lingüísticos y teórico-literarios, singularmente la obra ejemplar y modélica de Paolo Valesio (1980). Bernd Spillner, por ejemplo, aun confesando en 1977, en su contribución a la importante miscelánea editada por Plett, que los aspectos que él llama "científicos" de la Retórica, es decir, los que la orientan hacia una teoria de la producción y el análisis textual, primaban por entonces en el panorama de la readaptación de la nueva Retórica sobre los estric- 
tamente ideológico-prácticos (Spillner, 1977: 97), venía a reconocer en último término la práctica coincidencia de esos dos tipos de intereses. Spillner explicaba el auge neorretórico como una simple consecuencia de la ampliación interna de la Lingüística contemporánea, una vez desarraigado el modelo lingüístico reducido, que funcionó en los años precedentes entre el estructuralismo y el generativismo (Spillner, 1977: 99). Como el lingüista alemán, el gran filólogo italiano Luigi Heilmann ponía el énfasis en la coincidencia entre el desarrollo de la nueva Retórica y disciplinas como la Pragmática lingüística, la Socio- y Psicolingüistica, las Gramáticas textuales y el sector de los actos lingüísticos de la teoría de la comunicación (Heilmann, 1978; Leoni-Pigliasco, 1979).

Personalmente considero muy positiva la existencia en el fondo de este acuerdo de intereses interdisciplinarios. Al mismo tiempo, me parecen desaconsejables todos los excesos polémicos contra posturas y opiniones ajenas, o sobre todo de otros sectores científicos. Si es cierto que los lógicos tienen toda razón para entusiasmarse con los resultados futuros de la investigación de límites y contigüidades entre la inventio retórica y la Dialéctica, y que ese mismo derecho al entusiasmo puede asistir con justicia a los cultivadores de la teoria de la comunicación, no es menos verdadero que la Retórica lingüistica y la literaria han sido durante siglos, gracias a su propio desarrollo - aun hipertrófico- las únicas que han mantenido el recuerdo de un sector de los logros retóricos (R. Barilli, 1979). En tal sentido se expresa y se falsea pura y simplemente, cada vez que se renuevan - y en los últimos tiempos ha sucedido con frecuencia excesiva- las acusaciones de borrado de sectores y de doctrinas retóricas atribuidas en exclusiva a una suerte de imperialismo de lingüistas y poetólogos, que ya se manifestaria en la edad greco-latina. Como si a los propios responsables, antiguos y modernos, del cultivo de la Dialéctica o de la Lógica, no les cupiera mayor responsabilidad en esos olvidos y abandonos. No dudo, por tanto, en modo alguno de la urgencia e importancia de replantear, desde los datos ofrecidos por los retóricos y dialécticos de todos los tiempos y las enriquecedoras perspectivas más actuales de ciencias como la Lógica o la Teoría de la Comunicación, una renovación y reactualización con base retórica de la teoria de la argumentación y de la persuasión. Pero es obligado reconocer que esa iniciativa está aún, por 10 menos, tan sucintamente abocetada y remotamente descrita en las más avanzadas y agresivas propuestas de los teóricos de la comunicación (Mosconi y otros, 1981), como en las más tímidas y conservadoras formulaciones de lingüistas y poetólogos (Varios, 1976). En tal sentido, quizá siga siendo exacto reconocer con E. Black hace ya casi veinte 
años que, pese a su indiscutible interés, los métodos neorretóricos en todos sus aspectos y perspectivas distan mucho de hallarse aún en punto de densidad y variedad realmente reconocible (Black, 1965: 1718).

Más útil, pues, que disolver el propio esfuerzo en acusaciones estériles es, a mi juicio, reconducir, cada uno según sus respectivos intereses y tareas, ese común acuerdo que propende a asentar sólidamente la Retórica como teoría y práctica de la persuasión. Únicamente así, merced a la recuperación del carácter "abierto" y "popular" que ostentaba en sus versiones clásicas, se disiparán definitivamente las prevenciones modernas contra el caparazón de uformalismo tecnológico y aristocratizante", dentro del cual la Retórica aparece inmovilizada según muchos autores desde el Humanismo renacentista (L. Bornscheuer, 1977: 204-208). No se olvide, sin embargo, la persistente explicitud de la antigua Retórica a este respecto. El concepto central del docere retórico traduce simpiemente una de las fórmulas prácticas en que cristaliza el proceso de persuasión, endulzado por el delectare y ordenado al movere. Quizá sea oportuno destacar, en este punto que se repite tantas veces automáticamente, cómo fue el ideal de persuasión retórica el que invadió durante siglos el apartado correspondiente a la Poética. La Retórica suponía en cualquier hipótesis una ciencia y actividad más incuestionablemente práctica y utilitaria en sus fines que la Poética. Sin embargo, ya la Poética de Aristóteles ofrece puntos mucho más fácilmente integrables - como de hecho así ocurrió- en un ideal de didactismo-social vinculado sobre todo a los espectáculos dramáticos, que aquellas otras aseveraciones, menos manejadas, que hablan del placer artístico. Téngase presente, en cualquier caso, incluso la condición intelectualizada-reflexiva de ese único tipo de placer aludido por Aristóteles, quien al vincular el deleite como connatural a la mimesis, no hacia otra cosa que aludir a un proceso «artificioso" de reconocimiento de la realidad, a través del trámite de la confección de un verdadero modelo mimético de los objetos y acontecimientos reales, que es la reproducción artística (C. Segre, 1978: 179-185). A su vez Horacio retorizaria definitivamente esta estrecha alternativa a las de finalidad del arte, a través de su famosa fórmula versificada: "aut prodesse volunt aut delectare poetae, / aut simul...".

Sin embargo, la tradición más propia y genuinamente poética de la Antigüedad excedía bastante, en el dominio de la conciencia de creadores y preceptistas literarios, esta estrechez de miras relativa a los efectos y finalidades de la literatura, y singularmente de la poesía. Baste recordar, junto al caso del platonismo que fue sin embargo muy tempranamente captado por el patrón oficialista aristotélico, el relati- 
vismo escéptico de los sofistas, cuya influencia o coincidencia en amplios sectores y actitudes de la práctica artística debió de ser muy importante. Semejantemente, la obligada y documentada incidencia sobre las ideas de poetas y preceptistas en estos temas cruciales de las difundidas "escuelas morales" grecorromanas, singularmente los epicúreos y estoicos. Autores modernos como Jensen y Rostagni han reexhumado documentos inestimables en tal sentido, como son las ideas estéticas de Filodemo de Gádara (Jensen, 1923; A. Rostagni, 1930: 94-112; Garcia Berrio, 1977-80; I: 367-369), destacando su difusión e influencia en los medios artísticos y sociales de la Roma imperial. Singularmente un tratado como el De Sublime del Seudo-Longino manifiesta, rotundamente, toda una actitud alternativa en el pensamiento sobre la esencia y finalidad del arte, que hoy podriamos denominar estético-hedonista, frente al didactismo moral de la ortodoxia retórico-aristotélica, acuñada bajo formas definitivas por Horacio y Quintiliano y radicalizada y preservada en el tiempo a través de la autoridad moral de la Iglesia Católica (Garcia Berrio, 1981a). La presencia, por tanto, de los ideales retóricos, gobernando el destino y la finalidad del discurso literario fue, hasta tiempos relativamente recientes, un hecho casi sin excepciones, por lo que a la reflexión teórica sobre el discurso artístico se refiere. Cosa distinta en muchos casos, pero no en todos ni siquiera en la mayoria, es lo que se tradujo a la realidad de la práctica artística. Los más geniales creadores supieron siempre independizarse, con concesiones nunca pequeñas después de todo, a las ideas teóricas oficiales; descubriendo intuitivamente y en el ejemplo de sus antecedentes y modelos la vía de una actuación y persuasión poética autónomas de los ideales de estricto didactismo civil y democrático difundidos como finalidad central desde la Retórica. Podemos decir, en sintesis, que si a efectos del recorte de su contenido a elocutio se ha hablado de un proceso de poderosa poetización de la Retórica, la tendencia inversa de retorización de la Poética y de la Literatura es una realidad de alcance indiscutible, a la luz de fenómenos como el que acabamos de señalar, que podriamos fácilmente extender a otros muchos dominios doctrinales, como de hecho indirectamente se deja ver en numerosos lugares de este trabajo.

La presencia y alcance de los ideales retóricos del discurso, como proceso de persuasión orientado a la acción moral, individual o colectiva, en que se cruza, como acabamos de señalar, uno de los grandes centros de gravedad de la Retórica tradicional con una tendencia muy mayoritaria y ramificada de los intereses de la actual Neorretórica (P. Valesio, 1980), nos proponemos descomponerlo para su análisis en este trabajo dentro de dos apartados distintos: la reflexión sobre el 
carácter ejemplar al respecto de las doctrinas antiguas, en primer lugar; y, en segundo término, la traducción del principio general de la persuasión a términos bien conocidos, pero desde perspectivas de enjuiciamiento distintas, del discurso general y literario moderno.

a) Propongo, en primer lugar, que lo que subyace a la enumeración tradicional de los fines de la actividad retórico-poética: enseñanza o provecho como fin último, deleite como vehículo o fin instrumental, y conmoción y acción como traducción final pragmática de los otros dos fines, sea interpretado para su adecuada comprensión actual, no amortiguada por el hábito, como un proceso consciente, cuidadosamente graduado de intercambio de valores entre el emisor del discurso --«rétor", poeta o persona en actitud general de persuadir- y el receptor del mismo, que puede ser el juez o jueces de la causa, un auditorio, un jurado, un colectivo de potenciales compradores o votantes, el público de un teatro, el lector individual de una novela o poema equipado con sus propios valores y creencias en convivencia o en contraste con los valores objeto de la transmisión persuasiva, etc... Resulta útil fijar la voz y concepto de valor como término inicial de la persuasión adscrito al emisor; especializando un concepto y denominación distinta, estimación, como resultado de la aceptación o rechazo por parte del receptor individual o colectivo de los valores objeto de la propuesta y la argumentación retórico-persuasiva.

Esta visión en términos valorativos de la eficacia actuativa de la literatura conectaria con tradiciones muy remotas de interpretación moral de la función literaria y, en general, artística; si bien, por otra parte, produce una de las más profundas y matizadas formulaciones del sociologismo literario, cuales son las doctrinas de Bachtin sobre la "polifonia" social perceptible en la novela (M. Bachtin, 1970a). El énfasis de Bachtin, sin embargo, se concentró casi exclusivamente sobre los aspectos de representación de la variedad social en la pluralidad de registros expresivos albergados irónicamente en la gran novela burguesa moderna desde Cervantes a Dostoyevsky (Bachtin, 1978: 122151), traduciendo asi su conciencia lingüística de la entelequia sistemática de la "langue" como constructo puramente especulativo, frente a la única realidad concreta de la "parole» -actuación (Bachtin, 1977 - _. En tal sentido conviene no extralimitar el alcance de expresiones clave en las ideas literarias de Bachtin, poniéndolas al servicio de interpretaciones más o menos "ad hoc» y ocasionales fácilmente reconducibles a nuestros propósitos. Tal sería, sobre todo, la aproximación del que Bachtin denomina factor ético como tercer componente -junto al representativo y el estético- de una poética social-estética, 
y no estrictamente material al modo de la practicada en su opinión por los formalistas rusos (Bachtin, 1978: 51-52). Adviértase bien, no obstante, la absoluta desvinculación, salvadas las más superficiales apariencias, de ese "factor ético" con ninguna reflexión retórica vinculable a la dimensión de convencimiento moral del lector, intercambio de sentimientos entre emisor y receptor a través del texto, o sencillamente argumentación persuasiva ejercida en términos de ética, tal como se encubre en mi propia propuesta de registro ético-retórico del discurso literario en términos de valores/estimaciones.

El alcance del componente ético en el entendimiento de la novela por parte de Bachtin se refiere precisamente a uno y el mismo requisito aristotélico de «hombres en acción», a través del cual Aristóteles concretaba directamente la peculiaridad estructural de la tragedia, e indirectamente su delimitación muy estricta, didáctico-social, de la función literaria (García Berrio, 1981a: 507-508). El personaje de la novela, carácter o ethos en la tradición poético-retórica, constituye el vehículo o soporte ficticio de una determinada modalidad social de discurso, incorporada a la polifonía de la novela, como equivalente literario del orden general social. A través de la encarnación en el lenguaje de los personajes de los diferentes registros de actuación lingüística - $\mathrm{O}$ al menos de los más característicos y representativos - conllevados como en suspensión simultánea en el idiolecto social, la novela cumple su finalidad y función. El arte del novelista, y su mérito en consecuencia, estriba precisamente en su capacidad de encarnación ética a través de la voz de sus personajes, de la pluralidad de registros constitutiva de la situación social concreta (Bachtin, 1970a: 194-6). Como puede verse, con tal tipo de consideraciones no transcendía Bachtin la estricta esfera de la descripción estructural de las peculiaridades del texto de la novela. Sus ideas se movían exclusivamente dentro del mismo horizonte de ambiciones explicativas de aquellas mismas poéticas logocéntricas, centradas en el texto como producto y no como vehículo de intercambio, que él mismo, bajo otros presupuestos y experiencias, criticaba.

No obstante, resulta evidente desde otro aspecto la fácil circulación desde las ideas de Bachtin sobre la "pluralidad de voces» a la interpretación retórico-pragmática del texto literario, y muy singularmente de cualquier tipo de texto con personajes, como modalidad de discurso persuasivo-argumentativo, que propicia el intercambio ético, de comportamientos morales y convicciones ideológicas, entre emisor y receptor. Las voces de los personajes constituyen, a mi juicio, una primera instancia a través de la cual el autor no sólo recoge y describe los elementos en presencia de la situación social, sino que se sirve de ellos, 
sobre todo, para presentar su propia interpretación del mundo en términos intelectuales y morales. La veracidad expresiva de los personajes, su eficacia de representación social, es al mismo tiempo el vehículo de verosimilitud eficaz exigido al novelista por sus lectores como condición imprescindible para cerrar, con la lectura, el pacto de entusiasmo fantástico a través del cual se examina el sistema de ideas del autor, su capacidad de enjuiciamiento social y moral del mundo. El autor mueve sus tesis, dejando asociar sus propias preferencias merced a procedimientos fácilmente reconocibles por su público: el más común de ellos es la simpatia. El autor reviste sus ideas más encariñadas sobre el mundo mediante los rasgos de contenido semántico y aun de subrayado funcional estructural que delinean inconfundiblemente al héroe y al antagonista. De tal manera que, tan eficaz como es el propio subrayado de atractivos con que se convencionaliza el valor virtuoso del héroe, suele ser la representación antipática de los contravalores del antagonista villano en el tipo de la novela burguesa de Stendhal a Balzac, de Dostoyevsky a Toistoi.

La eficacia de un autor suele atribuirse precisamente a su capacidad de entusiasmar al público, de contagiarle e imponerle sus propios códigos de estimativa. A este respecto poco importa que un escritor o un novelista se enfrenten de hecho con un sector de la sociedad contemporánea o incluso con toda ella; si precisamente se han fijado como propósito provocarla bajo la forma de un afrontamiento como sátira generalizada. Se trataría del caso no infrecuente de los valores para la posteridad, como los que pudieran representar entre la mayoria de sus contemporáneos Sade o Lautréamont. En casos tales la persuasión, si es realmente eficaz, se dirige a un código futuro, saltando sobre el sistema contemporáneo de valores que lo rechazan totalmente. Situación mucho más frecuente, singularmente en la literatura moderna, es el caso del rechazo parcial del sistema de valores de un autor por un sector más o menos mayoritario de sus contemporáneos, como sería el escándalo anticlerical de Galdós en la España del siglo pasado, o el enfrentamiento por causas de incomprensión conservadurista hacia Borges en el presente. Todo ello apunta a que el lector individual o las formaciones colectivas de lectores no aparecen inermes al sistema de valores propuesto por un autor a través de la seducción de su argumentación simpática; antes bien lo afrontan y examinan implacablemente, adhiriéndose a él o rechazándolo en términos de desdén o incluso de exasperación por virtud de los misteriosos mecanismos ilusorios de la ficción verosimil artística. Si por parte del autor la obra literaria cubre la propuesta de seducción como sistema de valores, que pueden configurarse incluso, según señala Black (1965: 150), como un intento de 
complicidad en un sistema de prejuicios, el lector dispone de un campo propio de maniobra en el que caben tanto la adhesión como el rechazo (Black, 1965: 161), la solidaridad y la discrepancia. A ese campo exclusivo de las decisiones simpáticas del lector respecto de las tesis ofrecidas por el autor a través de las ficciones del texto, se le podria denominar apropiadamente ámbito de estimaciones.

La estimación del lector puede coincidir total o parcialmente con el sistema de valores del escritor. Una coincidencia amplia establece los supuestos de entusiasmo, generalmente vinculados a la sanción pública de éxito literario; por el contrario la estimación negativa, que opone valores y estimaciones, se traduce en el fracaso o rechazo momentáneo o definitivo de la obra. Adviértase bien que los términos extremos de la estimación, el entusiasmo y el rechazo, apelan a un tipo de solidaridad ética entre el escritor y su público; no atañen propiamente a la eficacia formal artistica de la obra. No obstante la solidaridad ética va intimamente vinculada al grado de eficacia en la representación artística de la tesis moral, como señalara el mismo Bachtin (1978: 52-53), ya que en definitiva lo propio de la argumentación artística es la seducción del lector por la simpatia de la representación. Asi se explicarian los desajustes del código moral atribuibles a capacidad de subversión de los artistas, con episodios que van desde la tan recordada expulsión platónica de la República o la condescendencia con el "picaro" en la novela del XVI, al satanismo de un tipo de héroes románticos de Byron o Espronceda, o incluso al protagonismo simpático del malvado en ciertos géneros de literatura de masas y de "comics" en nuestros días. La correlación entre eficacia estética y estimación no acomuna en verdad factores análogos, pero se rige evidentemente por reglas relativamente fijadas, no difícilmente establecibles, aunque no sea éste el momento adecuado de desarrollarlas.

Es bien conocida por otra parte, en relación a los mecanismos de interacción valor-estimación, la inmensa casuística histórica que combina las variables de adhesión y rechazo contemporáneos con su inversión posterior, o con su mantenimiento permanente, y uno y otros supuestos referibles tanto a la escala de la vida del lector singular, como al caso del éxito y el fracaso sociales, colectivos. En definitiva se trata de un juego de acomodación de la eficacia del propio discurso al lector implicito (Iser, 1976), que puede coincidir o no con el tipo más inmediato y generalizado de lector, o bien con un lector marginal o con un lector futuro. Debe contarse, por último, con el supuesto más común de los altibajos y desigualdades en el proceso permanente de estimaciones sobre una obra, singularmente ilustrativo como episodios de cambio de gusto y de orientación moral en el transcurso de las diferentes épocas. 
El concepto de valor propuesto implica, desde mi punto de vista, los tres fines canónicos de la Retórica como componentes parciales, en la medida en que propone un objeto ético conceptualizado (docere), que se participa atractiva, eficaz y adecuadamente a través de los mecanismos de la persuasión (delectare), y que al tratarse de un objeto ético, supone obligatoriamente un movimiento de adhesión o de rechazo (movere) que establece la solidaridad entre valores y estimaciones como resultado del intercambio comunicativo-retórico, o bien la discrepancia, como efecto de insolidaridad.

b) Es bien sabido cómo la discusión en torno a los fines del discurso constituyó una de las partes básicas del «corpus» doctrinal de la Retórica, transferido muy tempranamente a la Poética; sobre ello no creo necesario extenderme en más consideraciones informativas ( $R$. Barilli, 1979). Por lo demás el debate, bajo formas muy distintas, no se halla ausente tampoco de algunos de los procesos de discusión modernos sobre la esencia y función de los varios discursos artísticos; y se involucra e implica igualmente en la explicación actual de aspectos de recepción (R. Warning, (ed.), 1975; G. Grimm, 1977) y lectura (H. Weinrich, 1971; M. Charles, 1977), bajo los cuales indirecta y quizás hasta involuntariamente se está tratando de soslayar definitivamente el callejón sin salida de los debates sobre la «poeticidad», en sus equivalentes más concretos y positivos en términos de factor de mediación (J.M.Klinkenberg, 1977: 87). Respecto a la primera vertiente de la cuestión,es bien sabido que ha sido casi absoluto desde el segundo decenio de este siglo el protagonismo de la discusión sobre la finalidad del arte entre marxismo y vanguardismo formalista, con un conjunto de altibajos sobradamente conocidos (Garcia Berrio, 1973: 367-404). Sin embargo parece que empieza a verse camuflado sólo en estos últimos años, mediante la generalización en Occidente de ideologías artisticas sustancialmente lúdicas, contraculturales, ecologistas, etc...

Quizás mayor interés técnico, pero seguramente análogas motivaciones de fondo son las que se pueden describir en otras corrientes de la investigación metodológica reciente sobre el intercambio pragmático del discurso. Entre los de menos difusión literaria se situaria el conjunto de iniciativas de naturaleza más estrictamente pragmática, mayoritariamente vinculadas a la teoría del «speech act» (M.L. Pratt, 1977), en las que yo colegía la expresión global de una "propuesta pragmática" de literaridad (García Berrio, 1979: 127-130), así como la ya muy elaborada expresión de una teoria empírica de la literatura, elaborada sobre los supuestos de una estadística social de la apreciación por Siegfried J. Schmidt (1979). Tales iniciativas no se desarrollan muy lejos, 
pese a sus apariencias quizás más superficiales, de la actividad mejor conocida de los grupos que han especializado la investigación tradicional sobre las peculiaridades del discurso literario como teoria de la recepción/interpretación (T. Albaladejo Mayordomo, 1981: 120-130) y retórica de la lectura (Weinrich, 1974, Iser, 1976; M. Charles, 1977).

2.3. Del conjunto de observaciones practicadas en el párrafo anterior (2.2), podemos afirmar nuestro convencimiento de la utilidad y pertinencia científica actuales de una Retórica general como retórica de la apreciación (Black, 1965: 61). La cuestión siguiente se plantearia en términos de determinar exactamente los principios y operaciones imprescindibles para llevar a cabo una aspiración a todas luces necesaria y útil. Una vez más, e incluso en este caso con mayores elementos de convicción, he de reiterar mi postulado básico para la constitución actual de una Retórica general moderna, de que las canteras doctrinales de la Retórica tradicional, adecuada y exhaustivamente investigadas, podrán colaborar en esta tarea solo a título de base suplementaria, por grande que sea la importancia de su aportación, que yo no regateo (P. Valesio, 1980). Sin embargo me parecería sencillamente inadecuado desconocer el valor-directriz que, en un planteamiento global del discurso retórico - general y literario- como proceso de persuasión, es obligado asignar a componentes teórico-lingüísticos actuales tales como la teoria de los actos de lenguaje (Searle, 1969), la Pragmática lingưistica (Breuer, 1974; 1977: 238; T. Albaladejo Mayordomo, 1983), la teoria de la comunicación (Kopperschmidt, 1976: 45-49); o la teoría de la argumentación (Olbrechts-Tyteca, 1970). Globalmente hablando, la función retórica de la persuasión puede adquirir hoy quizás su genuina fisonomía asi como toda su originaria virtualidad analítica y predictiva, gracias al trámite habitual de su enfoque como una más de las perspectivas pragmáticas del intercambio lingü ístico, funcionando precisamente dentro de los supuestos lingüistico-textuales que establecen el marco adecuado de la organización psicológica y expresiva de la macroestructura textual. Pero no conviene tampoco olvidar a este respecto, que, si bien parece lo más adecuado insertar los datos y observaciones de la Retórica tradicional en el marco creado por modernas disciplinas lingüisticas como la Pragmática y la Gramática textual, el desarrollo doctrinal especifico de una teoría pragmática de la influencia o la persuasión, adecuadamente ordenado para recibir el enriquecimiento de un componente privilegiado de considerable riqueza como la experiencia retórica, no se halla aún adecuadamente desarrollado. Quizás en éste, como en otros muchos aspectos de la cuestión, la colaboración 
de la Retórica con la Lingüística, en el proyecto de una Retórica general, irá descubriendo por sí misma paulatinamente las etapas dentro del mismo proceso de colaboración (Mosconi y otros, 1981).

Complementariamente, la experiencia histórico-literaria puede ofrecer quizás, a su vez, las pautas más seguras y concretas en este aspecto dentro del proyecto general de colaboración de la Retórica tradicional con las distintas disciplinas modernas del discurso en el proyecto de formación de una Retórica general, tal como lo venimos presupuestando en este estudio. En efecto, la rica casuistica que ofrece la historia literaria en cuanto historia de los avatares y altibajos en la estimación de las obras literarias, puede ofrecer excelentes pautas de observación, tanto en general como sobre textos muy en concreto, para elaborar esta teoria de la persuasión retórica en el marco de una Retórica general. El seguimiento detallado en los textos concretos de la estructura de sus valores y sobre todo de los artificios y mecanismos específicos para imponer su aceptación en estimación positiva, constituyen sin duda una tarea no demasiado desarrollada todavía como operación retórica consciente por los historiadores de la literatura. Sin embargo los cálculos implícitos de tal tipo de exámenes no resultan demasiado comprometidos ni problemáticos. Conociendo de antemano, como es el caso de las obras del pasado, el resultado de la sanción histórica de la estimación del público sobre autores, obras, ideologias y sistemas morales, resulta relativamente sencillo e inmediato fijar las constantes generales del éxito o el fracaso persuasivos, asi como describir el cuadro de los procedimientos especificos a los que va vinculado el resultado feliz de la argumentación en un texto, autor o época determinados. De las casi infinitas observaciones concretas de este tipo practicables, una inteligente selección de las mismas, adecuada al tipo de experiencias o conclusiones que se pretenda establecer, ofrecería con toda seguridad un "corpus" suficiente para abordar las fases descriptiva y predictiva, así como la sistematización del componente pragmático-persuasivo, en especial de la futura Retórica general. Dicho componente influiría de manera sobresaliente en el establecimiento de una Retórica especificamente literaria.

Sector privilegiado para el seguimiento de las estrategias persuasivas, dentro del plano formal de una teoría de la argumentación retórica, es el que ofrece el rico arsenal de doctrinas tradicionales relativas a la estructura de la causa, o partes del discurso: exordio, narración, argumentación - con su bipartición optativa en probatio y refutatio- y conclusión. Condición previa, sin embargo, para su aplicación fecunda al tipo de exigencias argumentativas impuesto en la Retórica general que trato de bosquejar, será quizá la de atenuar el énfasis tradicional 
de tales doctrinas en los tratados retóricos, enfocadas por lo común bajo la perspectiva preferente del hallazgo de argumentos. Con lo que se explica el desarrollo excepcional de la doctrina especifica de los loci, correspondiente a los "argumenta», frente al mucho más reducido desarrollo de las modalidades de «exempla» y "signa», las otras fuentes al mismo nivel de la probatio artificialis como parte de la argumentatio. El énfasis sobre la dimensión persuasiva de la Retórica que favorece, como es sabido, el tipo de aplicaciones de la misma tanto a una Retórica general del discurso como, sobre todo, a una Retórica literaria fundamentalmente formalista, presupone desatender la dimensión más propiamente de inventio en la teoría de las partes de la causa, y fijarse prioritaria y preferentemente en el encadenamiento y sucesión de tales partes, con sus subcomponentes respectivos, dentro de una perspectiva argumentativa que se vincularia claramente a intereses de dispositio.

La consulta sobre el género de consejos relativos a la eficacia del exordio, asi como la perfecta y exhaustiva gradación de los subcomponentes de la narratio justificada en un gran número de tratados de Retórica -initium, digresio, transitus, propositio, expositio (Lausberg, 1960: $\S \S 338-347$ ) — pueden brindar pautas seguras y muy clarificadoras del modo en que se trata de vincular la atención y el favor del oyente, juez o auditorio, en términos de estimación, a la exposición, como valor, del punto de vista de la propia causa llevada a cabo por el orador, abogado o no. Asimismo dentro de la probatio artificialis los «argumentos» propiamente dichos (Lausberg, 1960: $\S \S 366-409$ ), más que los "exempla» o los "signa», ofrecen un interés doblado al mismo respecto, en la medida en que no se trata de piezas fijas incluidas como tales en la estructura del texto en tanto que proceso de conocimiento, como lo son las otras dos modalidades de recursos de prueba (Black, 1965: 125), o, en la medida en que por su propia estructura el argumento se ofrece como esquema organizado en partes y ordenado globalmente a la persuasión por si mismo. Tal rasgo se intensificaría por excelencia en el "entimema", y resulta semejantemente ilustrado por las otras dos modalidades de la "ratiocinatio", a saber, el "silogismo» y el "epicherema». Más inequívocamente vinculados a la esencia de la inventio, los famosos "loci communes" constituyen, en términos de la célebre caracterización de Quintiliano, "sedes argumentarum" (Lausberg, 1960: § 373), fuentes por tanto de los esquemas argumentativos y centro del entimema (Bornscheuer, 1977: 210), actúan persuasivamente más que organizaciones esquematizadas de la procuración verbal de convicción. 
3.0. Con el acceso a sectores de la teoría retórica más inequivocamente correspondientes a dispositio aumenta la firme orientación comunicativo-pragmática que va descubriéndose en el trazado futuro de una Retórica general como ciencia de la expresividad persuasiva, y que puede ser igualmente palpable y verosímilmente productiva en una modalidad no amortiguada y "tecnológica" de la Retórica literaria, sustentada fundamentalmente en mi propuesta como la dialéctica entre valores y estimaciones desarrollada artísticamente en el seno del texto literario, poético o novelesco. La dispositio, como ya to hemos señalado profusamente en este trabajo, fue la dimensión retórica más precozmente invocada como antecedente por las modernas gramáticas textuales (van Dijk, 1972: 24). La inmediatez de sus postulados constitutivos a los de una imagen del texto fundamentalmente provista por el estructuralismo resulta evidente. Existe sin embargo el problema, menor y subsanable, de que los esquemas estructural-argumentativos de la dispositio textual no suelen quedar consignados en los modernos manuales y síntesis de Retórica, centrados más bien en seguir sus fuentes clásicas en la exclusiva vertiente de las modalidades de «membración» del periodo o, cuando mucho, del parágrafo. Como ya hemos señalado, la revisión en este caso de esas fuentes principales, y sobre todo la atenta consulta de las usualmente marginadas artes concionandi y dictaminis medievales (Th. M. Charland, 1936; P. Zumthor, 1971, 1972,1975 ), puede ofrecer servicios muy brillantes a la futura Retórica general o a la actual Retórica literaria, en su doble vertiente de desarrollo de esquemas de combinatoria estructurales propiamente tales, y sobre todo en la dimensión intencional de los mismos como estructuras muy complejas y refinadas de argumentación persuasiva. En términos propiamente retóricos, distinguiendo entre compositio, es decir: "estructura sintáctica de la frase continua» (Lausberg, 1960: § 911), y dispositio, aquélla correspondería al concepto actual de composición microcomponencial-sentencial del texto, y ésta a la composición o estructuración del macrocomponente textual; siendo obviamente esta última, la más habitualmente desatendida, la que reviste un mayor interés para la revisión moderna de la Retórica tradicional.

Igualmente interesante y con relieves actuales dentro de los problemas de dispositio resultan las cuestiones retóricas de ordo. Las estrategias del ordo artificialis cuentan igualmente dentro de la dimensión pragmático-argumentativa de una Retórica general del discurso (Valesio, 1980; Mosconi, 1981), en la medida que suponen esquemas de manipulación consciente y de gradación y acomodación de las piezas constitutivas del proceso persuasivo (D. Breuer, 1974). Por muy equivalentes razones, las consideraciones de orden resultan capitales en los 
fenómenos literarios dependientes de la gradación del interés, desde los bien conocidos esquemas de ponderación conceptuosa del metaforismo catacrético barroco a las estructuras no menos populares de intriga y "suspense» de los actuales relatos policíacos. Sin embargo quisiera destacar aquí un ejemplo de posible articulación de estas cuestiones de ordo con una de las más recientes propuestas de Retórica literaria: la que, sobre todo en el dominio francés se va estabilizando como poética de lo imaginario (poétique de l'imaginaire). Me propongo detenerme, además, en el examen de esta cuestión específica en la medida en que por sí misma me permitirá conectar estas consideraciones sobre la dispositio con la quizá única temática transcendente de la elocutio, cuyo examen resulta inabdicable en el tratamiento de cualquier Retórica moderna, de intereses generales: la cuestión de las figuras o "esquemas de expresión».

La de "imaginario" viene siendo, dentro de la crítica francesa de los últimos diez o quince años, una de esas categorías generales, de uso no demasiado específico, que súbitamente pasan a convertirse casi en un tecnicismo con vocación unívoca fuertemente señalada. No es difícil rastrear sus orígenes próximos en ciertas peculiaridades de la fantasía romántica, plástica y literaria (J. Pierrot, 1963; R. Caillois, 1974). Hasta este punto las vinculaciones entre el imaginario y la estructura retórica del ordo artificialis no pasan de ser de tan genérica y común semejanza como puedan serlo otras muchas cuestiones relativas a la artificiosidad convencional de la expresión artística. Sin embargo, una de las acepciones menos vagas en las que ha venido a caer la noción - por otros conceptos y casos demasiado ambigua en la proliferación actual de su uso en cierto sector de crítica francesa- es la muy reciente de estructura asociativa de las imágenes en el seno del texto, en una de las obras más recientes que ha inspirado esta difusa categoria (J. Burgos, 1982: 13-15).

Esta noción de imaginario redime para la Retórica general en buena medida y de un solo golpe las tradicionales especulaciones sobre los tropos y en general sobre las figuras de dicción y pensamiento. $\mathrm{Ni}$ todos los esfuerzos de sus sistematizadores modernos (Leech, 1966; Todorov, 1967; Dubois y otros, 1970; Plett, 1971, 1977, etc.), ni los intentos más imaginativos de constituirlos como centro de una teoria del discurso literario (Genette, 1966; Groupe $\mu$, 1977; Klinkenberg, 1977: 86) resultan en si mismos consistentes. La poderosa tradición retórica de los tratados de las figuras, exiguo resto en la Retórica literaria de la decadencia de la vieja ciencia general clásica del discurso expresivo, puede explicar los intentos de convertirlos en centro de una pretendida Retórica general, que informaría por «proyección» los demás dominios 
de esa ciencia de vocación global (Bonheim, 1977: 109-114; Bornscheuer, 1977: 210). Incluso el más serio y argumentado intento en tal sentido del grupo de Lieja se vio considerablemente automoderado en el paso de su Rhétorique générale, de 1970, a la Rhétorique de la poésie, siete años posterior, siendo además objeto de buen número de reticencias (B. Spillner, 1977: 104-105). Entre los logros definitivos de los trabajos recientes de sistematización de figuras no parece razonable situar sino todos los méritos alcanzables por una excelente reactualización y racionalización de los inventarios inorgánicos de los viejos tratados de la decadencia -ordenados a veces por criterios tan probadamente externos y gratuitos como el de orden alfabético-, fruto de la etapa "abierta y popular de la Retórica» (Bornscheuer, 1977: 204), a una brillante esquematización de apariencias muy simples fundada en criterios constantes de razonable medularidad lingüística, especialmente en el caso del Grupo $\mu$ (1977: 133-137; Plett, 1977: 131). Sin embargo, quizá el mejor fruto de este persistente interés sobre el tratado de las figuras consista tal vez en la definitiva renuncia al proyecto ilusorio de construir en exclusiva con él -o desde él, en un segundo momento- el contenido inmenso de una teoría retórica de alcance global. Sin desconocer su importancia medular en la construcción de una Retórica general en los términos actualmente exigibles, el tratado de las figuras no llegaría hoy a cubrir, desde la ampliación moderna de la Gramática, la Semántica, la Pragmática y la Teoria del texto, ni siquiera el mayor espacio de las exigencias de una Retórica literaria lingüisticamente orientada.

Por contra, la ampliación de la teoría de las figuras aisladas al esquema textual de isotopía de imágenes que ha preconizado el sector de crítica, heredero de la tradición de espacialidad imaginaria en el texto ansiada por Bachelard, coloca a mi juicio el viejo apartado retórico de las figuras (Varios, 1980) en el centro mismo de especulación de la Retórica literaria, a la vez que ilustra brillantemente para la futura Retórica general del discurso un tipo de comportamiento asociativo muy singular en el seno del texto. La caracterización del papel estilístico del texto literario sobre la base de los tipos de asociación interselectiva de las imágenes componentes se completa mediante el estudio de la selección recíproca de esos mismos «metáboles"; en tales términos que el texto resultante quedaría configurado como el dominio donde se desarrolla una dialéctica de tensión estética, reciprocidad y complementariedad armónica de las figuras constitutivas de un proyecto equilibrado de recorrido imaginario en el seno de dicho texto. 
3.1. El examen llevado a cabo sobre el conjunto de presupuestos anteriores para una Retórica literaria constituyente de una Retorica general, nos sitúa ante un balance de cuestiones lo suficientemente complejo como para presupuestar a esa futura Retórica una amplitud respetable. Por otra parte, estoy persuadido de que una reflexión más pormenorizada sobre muchos de los puntos aquí solamente bosquejados, contando especialmente con el enriquecimiento categorial allegable desde la Teoría lingüística vigente y desde la Poética semiológica, ampliaría muy considerablemente el desarrollo de los referidos tópicos doctrinales (C. Segre, 1970: 63-75), engendrando a su vez otros nuevos y, sobre todo, fijando más nítidamente los enlaces y constelaciones dialécticos entre tales puntos de partida, relativamente autónomos aun al presente, y su dimensión interactiva en una teoría retórica integrada. Aun sin confiar en otro dato - que los hay, además- que en la misma experiencia de constitución de complejas teorias en el pasado, cualquier científico aun de mediana experiencia sabe que no estoy apelando a ningún género de cálculos abusivamente optimistas.

Sin duda mucho es lo que cabe esperar de la alianza y orientación de los viejos tópicos retóricos al amparo de las modernas orientaciones lingüísticas (Zumthor, 1975, 1978) siempre que el papel de la invocada Retórica no sea referido a un mero lugar común (B. Gray, 1977). Sin embargo no son menos importantes las perspectivas de desarrollo para una Retórica general contando con las aportaciones, ahora amortizadas, de amplisimos sectores doctrinales de la Retórica tradicional. Estas fuentes olvidadas han ido viendo cegada su comunicación con la corriente activa y renovada de la ciencia, en virtud de borrados materiales involuntarios o de exclusiones culturales conscientes, que las sacrificaron a la ortodoxia ideológica con la constitución de un "patrón" doctrinal aceptable y único, en el que dominaba casi como exclusiva la tendencia casi obsesiva a su perpetuación. De la importancia de ambos géneros de aporte se nutren básicamente las perspectivas futuras de una Retórica general; esto no me parece en absoluto cuestionable.

Más problemática, por el contrario, aparece la delimitación del futuro de esa Retórica general desde el punto de vista de su objeto. Las justas reclamaciones - hasta cierto límite de autocompasión injustificada - de ciertas posturas de tipo lógico expresando la necesidad de una articulación futura entre Retórica y Dialéctica, pueden contribuir a desdibujar en alguna medida los límites de alcance real objetivo de la Retórica en la zona de fáciles deslizamientos del lenguajepensamiento. Otro tanto, aunque con peculiaridades y desarrollos de distinto género, puede seguirse de la indistinción entre Retórica y Teoria de la comunicación, riesgo al que se asoman, incuestionablemente, 
algunas de las ofertas más prácticas de reimplantación de la Retórica como ciencia de análisis social (Kopperschmidt, 1976). La solución en ambas coyunturas pasa por evitar a partes iguales la tentación de una Retórica como pura «tecnologia» expresiva, lingüistica o literaria en cada caso; y frenar la propensión de signo contrario a una panretórica (Plett, 1977: 13-16) que acabaría pronto por vaciar de contenido a la Retórica general, en sus términos actuales de posibilidad y operatividad, sacrificándola en el mejor de los casos a la formación de una ciencia futura de la comunicación. El contenido del programa que queda bosquejado en este artículo, creo que por lo menos fija y defiende la capacidad animadora de una Retórica literaria de orientación general en la situación actual de clara crisis y de cambio en la Crítica literaria. Sean sus frutos concretos la constitución de una Poética interpretativa, mediando dialécticamente entre ella y la Teoría literaria, como quiere B. Lüking (1977: 53); o produzca, como calculo yo mismo, según se desprende de los datos y síntomas más significativos en presencia ( $P$. Valesio, 1980), la necesaria síntesis orgánica y no convencional, entre una Poética lingüistica de clara filiación material-formalista (Leoni-Pigliasco, 1979) y las propuestas de vario origen de una Crítica literaria de signo estético-social.

4. El conjunto de nuestras consideraciones a lo largo de este trabajo permite extractar las siguientes conclusiones, como presupuestos iniciales, pero ya operativos, para la constitución de una Retórica general literaria, o, si se quiere, de una Retórica literaria de base lingüística:

a) El renacimiento de la Nueva Retórica, especialmente en Europa, debe vincularse muy preferentemente a una más de las tentativas para superar la crisis reciente de la Critica literaria formal. Esta ha sido en gran medida una crisis de saludable superproducción; lo cual, sin embargo, no disminuye su entidad de crisis, ni deja de obligar a replantearse profundamente el estatuto mediador del discurso crítico en relación al texto artístico, asi como las cuestiones conexas del destinatario de dicho discurso y, en consecuencia, de los niveles de metalengua necesarios para cubrir todas las facetas de su funcionamiento.

b) La apelación a la Retórica tradicional, iniciada en el seno de la Semiología literaria y extendida en los últimos tiempos a la Lingüística por obra especialmente de la Pragmática y la Teoria de la comunicación, se ha encontrado con una Retórica empobrecida y devaluada desde su decadencia en el siglo XIX, una Retórica literaria. Resulta 
imprescindible y urgente recuperar de manera adecuada el pensamiento histórico sobre la Retórica, contemplándola en toda su verdadera extensión de ciencia general de la expresividad lingüistica. En tal sentido la Retórica general literaria, de cuyos fundamentos y directrices doctrinales me he ocupado en este trabajo, no deja de ser una parte imprescindiblemente ordenada a la Retórica general, como disciplina lingüística que tiene por objeto el discurso humano comunicativo.

c) En consecuencia de lo anterior, la relación entre los materiales provistos por la Retórica tradicional y los esquemas categoriales de la moderna Lingüística debería establecerse en todos los casos en términos de elemento complementario y directivo, respectivamente; habida cuenta de la fisonomia cientifica de la futura Retórica general.

d) La recuperación del pensamiento histórico de la Retórica tradicional es imprescindible. Dicha tarea debe extenderse a la mayor cantidad posible de documentos tenidos habitualmente por marginales, habida cuenta de la condición artificiosa y forzada de los varios "patrones", fuertemente prejuiciales, que han circulado, condicionándola, a lo largo de las diferentes épocas de la evolución del pensamiento poético-retórico.

e) Entre las tareas que se perfilan ya como básicas en la constitución de una Retórica general literaria, o si se prefiere de una Retórica literaria de base lingüistica, se señalan ya las siguientes:

I. Adaptación y regularización de la dualidad canónica res/verba, y de la serie triple de apartados-operaciones retóricas inventio/dispositio lelocutio a la realidad de la producción / estructura del texto en los términos que la ilustran los actuales conocimientos lingüísticos.

II. Proyección a las categorías y recursos del discurso moderno de las categorias retóricas tradicionales, convencionalizadas "ad hoc" para el llamado discurso clásico; como requisito imprescindible demandado por el objeto a una verdadera Retórica literaria de intenciones auténticamente «generales».

III. Profundizar singularmente las taxonomías tradicionales de tipos de discurso y modalidades textuales de la Retórica; asi como el complejo esquema tipológico de géneros y subgéneros de la Poética, con vistas a enriquecer y adensar los esquemas tipológico-textuales provistos por la Lingüistica y la Poética modernas.

IV. Investigar muy atentamente, con todo el pormenor documental histórico necesario, el complejo mundo de relaciones entre la inventio 
retórica y la disciplina Dialéctica, a fin de enriquecer y profundizar los actuales cuestionamientos científicos entre Lógica y Lingüística.

V. Sector particularmente privilegiado en la colaboración entre Retórica clásica y Lingüística actual es el que se opera entre la inabdicable condición argumentativo-persuasiva del discurso retórico y la dimensión pragmática del enunciado. Puede decirse al respecto que la conciencia de la eficacia persuasiva no está ausente en ningún punto de la teorización retórica; siendo, no obstante, singularmente reveladores los cuerpos de doctrinas tradicionales sobre la finalidad del discurso, así como las conclusiones deducibles de las disposiciones estratégico-estructurales de la dispositio textual en la organización de la exposición de la "causa".

VI. La importancia de la orientación argumentativo-persuasiva del discurso retórico no se reduce al tipo de enunciación literaria, sino que es más bien de alcance general, con poderoso relieve lingüistico, lógico y cognitivo. No obstante en el dominio de la literatura la adopción de semejante punto de vista adquiere relieves singularmente aclarativos, quizá más evidenciados hasta el presente en discursos literarios con personajes, pero fácilmente extrapolables a otros órdenes de la enunciación literaria y aun poética. La consideración del intercambio pragmático entre el sistema de valores del autor y el conjunto de estimaciones del público puede fundar una via de enjuiciamiento critico que incorpore a la aclaración crítica del texto las perspectivas de una teoría de la recepción y de la lectura centradas hasta el presente más bien en los aspectos del conocimiento.

VII. La doctrina tradicional sobre las figuras presenta, junto a la indudable ventaja de su persistencia tradicional, que llevó aparejado un grado de enriquecimiento que no conocieron los demás sectores preteridos de la teoría retórica, el indiscutible inconveniente de que su hipertrofia favoreció el olvido en la práctica de las demás partes doctrinales de la disciplina. Ésta pasó asi durante mucho tiempo por relativamente inoperante y desproporcionadamente reducida para el análisis de la complejidad textual. Tal grado de ofuscación y desconocimiento ha marcado además los primeros pasos de la reinstauración reciente de la disciplina como Retórica general.

VIII. En cualquier caso, disponemos del tratado de las figuras como el mejor articulado de los constituyentes de una Retórica general. Sin aceptarlo como base suficiente, en su estado actual, desde la que se pueda proyectar la fisonomía completa de la Retórica futura en todos sus dominios, su desarrollo me parece modélico, no obstante, para ilustrar el tipo de adaptación de los materiales clásicos al esquema categorial de las perspectivas metodológico-lingüisticas actuales. 
IX. La actual "poética de lo imaginario» permite ejemplificar eficazmente la vía por la cual la anquilosada retórica de las figuras, como piezas textuales sustantivas, puede desembocar en una retórica asociativa de las isotopias metafóricas de alcance holgadamente textual.

$X$. Los peligros de descarrío y falsificación que amenazan el proyecto actual de integración de la Retórica clásica dentro de la teoria general lingüística y crítica son muy numerosos. Vienen unos de la frivola invocación de criterios retóricos por parte de lingüistas, sin mayor conocimiento de causa doctrinal para designar muy primarias estrategias argumentativas de puro sentido común. Otras veces, aunque más raramente con intenciones de generalización, el fenómeno es inverso: reexhumaciones de materiales retóricos sin ninguna voluntad de insertarlos en una teoría general del lenguaje o la literatura; puro monumentalismo historicista. A veces se trata de desvinculaciones caprichosas y traumáticas de la exclusiva vertiente poética sin conciencia de su indefectible articulación integral lingüistica; en otros casos la ambición de generalidad en la capacidad explicativa de la ciencia se engaña sobre el alcance en realidad muy limitado de los presupuestos y materiales que pone en movimiento. El balance más prudente de todo ello, a la vista de los materiales y el volumen de cuestiones movilizados sintéticamente en el programa que he bosquejado, es que nos hallamos en presencia de las condiciones precisas para abordar con seguridad y frutos una Retórica general, a condición que sepamos resistir las tentaciones, de variado origen y alcances, de extraviarnos en una vaga e ineficaz tentación panretórica.

\section{Referencias bibliográficas}

Abad Nebot, F. (1982), Los géneros literarios y otros estudios sobre Filologia, Madrid, UNED.

Abad Nebot, F.; García Berrio, A. (eds.) (1982), Introducción a la Lingüistica, Madrid, Alhambra.

Albaladejo Mayordomo, T. (1981), "Aspectos del análisis formal de textos", en: Revista Española de Lingüistica, 11, 1, pp. 117-160.

- (1982), «Struttura comunicativa testuale e proposizioni performativo-modali», en: Lingua e Stile, 17, 1, pp. 113-159.

Albaladejo Mayordomo, T.; Garcia Berrio, A. (1982), "La lingüistica del texto", en: Abad Nebot, F.; Garcia Berrio, A. (eds.), pp. 217-260.

Alighieri, D., De vulgari eloquentia, ed. A. Marigo, Firenze, Le Monnier, 1968 (reimpr.). 
Alonso, A. (1969), Materia y forma en poesia, Madrid, Gredos.

Alonso, D. (1952), Poesia española, Madrid, Gredos.

Bachtin, M. (1970a), L'oeuvre de François Rabelais et la culture populaire au Moyen Âge et sous la Renaissance, Paris, Gallimard.

- (1970a), Problèmes de la Poétique de Dostoievski, Lausanne, L'Áge de l'homme.

- (1977), Le marxisme et la Philosophie du langage, Paris, Minuit.

- (1978), Esthétique et théorie du roman, Paris, Gallimard.

Baldwin, Ch. S. (1928), Medieval Rhetoric and Poetic, London, Mac Millan (reimp. 1959).

Barilli, R. (1979), Retorica, Milano, ISEDI.

Barthes, R. (1970), “L'Ancienne Rhétorique. Aide-memoire", en: Communications, 16, pp. 172-223.

—(1972), Le degré zéro de l'écriture, Paris, Seuil (reed., original 1953).

Becker, K. (1963), Das Spätwerk des Horaz, Göttingen.

Black, E. (1965), Rhetorical Criticism. A Study in Method, Madison, University of Wisconsin Press (reimpr. 1978).

Bonheim, H. (1977), "Für eine Modernisierung der Rhetorik", en: Plett (ed.) (1977), pp. 109-124.

Booth, W. C. (1965), "The Reviewal of Rhetoric», en: Publications of the Modern Language Association of America, 80, pp. 8-12.

Bornscheuer, L. (1977), «Zehn Thesen zur Ambivalenz der Rhetorik und zum Spannungsgefüge der Topos-Beggrifs», en: Plett, F. (ed.), pp. 23-44.

Bremond, C. (1966), "La logique des possibles narratifs», en: Communications, 8, pp. 60-76.

Breuer, D. (1974), Einführung in die pragmatische Texttheorie, München, Fink.

- (1977), “Die Bedeutung der Rhetorik für die Textinterpretation», en: Plett, F. (ed.), pp. 23-44.

Brink, C. O. (1961), Horace on Poetry, Cambridge University Press.

Bryant, D. C. (1967), Rhetorical Dimensions in Criticism, Baton Rouge.

Burgos, J. (1982), Pour une Poétique de l'imaginaire, París, Seuil.

Caillois, R. (1974), Approches de l'imaginaire, Paris, Gallimard.

Charland, Th. M. (1936), Artes Praedicandi. Contribution à l'histoire de la Rhétorique au Moyen Âge, Paris, J. Vrin.

Charles, M. (1977), Rhétorique de la lecture, Paris, Seuil.

Christensen, F. y B. (1967), Notes Towards a New Rhetoric, New York, Harper and Row.

Clarke, M. L. (1953), Rhetoric at Rome, London, Cohen and West.

- (1957), Rhetoric in Greco-roman education, New York. 
Collard, A. (1967), Nueva poesia. Conceptismo y culteranismo en la crítica española, Madrid, Castalia.

Curtius, E. R. (1955), Literatura europea y Edad Media latina, México, Fondo de Cultura Económica.

Dijk, T. A. van (1972), Some Aspects of Text Grammars, The Hague, Mouton.

- (1977), Text and Context. Explorations in the Semantics and Pragmatics of Discourse, London, Longman.

- (ed.) (1982), "New developments in cognitive models of discourse processing", número especial, 2, 1/3 (1982) de Text, The Hague, Mouton.

- Kintsch, W. (1977), "Cognitive Psycology and Discourse», en: Dressler, W. (ed.), pp. 61-80.

Dockhorn, K. (1968), Macht und Wirkung der Rhetorik, Bad Homburg. Dressler, W. (ed.) (1977), Current Trends in Textlinguistics, Berlin, De Gruyter.

Dubois, J. (y otros) (1970), Rhétorique générale, Paris, Larousse.

Eco, U. (1962), Opera aperta, Milano, Bompiani.

Faral, E. (1971), Les Arts Poétiques du XI/ et du XII/ siècle, Paris, Champion (reimpr.).

Fontanier, P. (1968), Les figures du discours, Paris, Flammarion.

Forastieri, E. (y otros) (eds.) (1980), On Text and Context. Methodological Approachts to Context of Literature, Puerto Rico, Universidad de Río Piedras.

Fowler, R. (ed.) (1966), Essays in Style and Language, London, Routledge and Keagan Paul.

Gadamer, H.-G. (1965), Wahrheit und Method, Tübingen, Mohr.

Garcia Berrio, A. (1968), España e Italia ante el Conceptismo, Madrid, CSIC.

- (1973), Significado actual del formalismo ruso, Barcelona, Planeta.

- (1973a), «La decisiva influencia italiana en la Ciencia Poética del Renacimiento y Manierismo españoles", en: Studi e problemi di Critica testuale, 7, pp. 135-160.

- (1975), Introducción a la Poética clasicista: Cascales, Barcelona, Planeta.

- (1977), «Crítica formal y función crítica», en: Lexis, 1, 2, pp. 187209.

- (1977-80), Formación de la teoria moderna, 2 vols., Madrid, Cupsa, Universidad de Murcia.

- (1979), «Lingüistica, Literaridad/Poeticidad (Gramática, Pragmá- 
tica, Texto)», en: Anuario de la Sociedad Española de Literatura General y Comparada, II, pp. 125-168.

- (1979a), «Text and Sentence», en: Petöfi, J. S. (ed.), vol.I, pp. 24-42.

- (1979b), "Construcción textual en los sonetos de Lope de Vega. Tipología del macrocomponente sintáctico", en: Revista de Filologia Española, 60, pp. 23-147.

- (1979c), «A Text-typology of the Classical Sonnets», en: Poetics, 8, pp. $435-458$.

- (1980), «Text Linguistics and the Lyric Text», en: Forastieri, E. y otros (eds.), pp. 95-138.

- (1980a), "Una tipología testuale di sonetti amorosi nella tradizione classica spagnola», en: Lingua e Stile, 15, 3, pp. 451-478.

- (1980b), "Quevedo y la conciencia léxica del 'concepto"», en: Cuadernos Hispanoamericanos, 361-362, pp. 1-16.

- (1981), "Macrocomponente textual y sistematismo tipológico: el soneto amoroso español en los siglos XVI y XVII y las reglas de género», en: Zeitschrift für romanische Philologie, 97, 1/2, pp. 146-171.

- (1981a), «Poetica e ideologia del discorso classico», en: Intersezioni, 3, pp. 501-527.

Genette, G. (1966), Figures I/, Paris, Seuil.

- (1968), «Prefacio» a la edición de Fontanier (1968).

Gray, B. (1977), The grammatical foundations of Rhetoric, The Hague, Mouton.

Greimas, A. J. (1966), Sémantique structurale, Paris, Larousse.

- (1970), Du Sens, Paris, Seuil.

- y otros (1972), Essais de Sémiotique Poétique, Paris, Larousse.

Howell, W. S. (1956), Logic and Rhetoric in England. 1500-1700, Princeton, Princeton Univ. Press.

Grimm, G. (1977), Rezeptionsgeschichte, München, Fink.

Groupe $\mu$ (1977), Rhétorique de la Poésie, Bruxelles, Complexe.

Gülich, E.; Raible, W. (1972), Textsorten, Frankfurt.

Habermas, J. (1971), Hermeneutik und ldeologiekritik, Frankfurt.

Hataway, B. (1962), The Age of Criticism, Westport, Connect., Greenwood (reimpr.).

Heilmann, L. (1978), «Retorica, Neoretorica, Linguistica», en: Ritter Santini, L.; Raimondi, E. (eds.), pp. 9-24.

Highet, G. (1954), La tradición clásica, México, Fondo de Cultura Económica.

Iser, W. (1976), Der Akt des Lesens, München, Fink. 
Jakobson, R. (1958), «Linguistics and Poetics», en: Sebeok, T. (ed.), pp. 350-377.

Jensen, C. (1923), Philodemus über die Gedichte, fünftes Buch, Berlin. Jones, L. K. (1977), Theme in English expository discourse, Lake Bluff (Illinois), Jupiter Press.

Kennedy, G. (1972), The Art of Persuasion in Greece, Princeton University Press.

Kibedi Varga, A. (1970), Rhétorique et Littérature, Paris, Didier.

Klinkenberg, J. M. (1973), "Le concept d'isotopie en sémantique et en sémiotique littéraire", en: Le français moderne, 41, pp. 285-290.

- (1977), «Rhétorique et spéficité poétique», en: Plett, F. (ed.), pp. 72-92.

Kopperschmidt, J. (1976), Allgemeine Rhetorik, Stuttgart, Kohlhammer (2. ${ }^{a}$ ed.).

- (1977), “Von der Kritik der Rhetorik zur kritischen Rhetorik», en: Plett, F. (ed.), pp. 213-229.

Kuentz, P. (1971), «Rhétorique générale ou Rhétorique théorique? », en: Littérature, 4, pp. 108-115.

Lachmann, R. (1977), «Rhetorik und kultureller Kontext», en: Plett, F. (ed.), pp. 167-186.

Lange, K. P. (1968), Theoretiker der literarischen Manierismus, München, Fink.

Lanhams, R. A. (1968), A Handlist of Rhetorical Terms, Berkeley.

Lausberg, H. (1960), Handbuch der literarischen Rhetorik, München, Max Hueber Verlag.

Leech, G. N. (1966), «Linguistics and Figures of Rhetoric», en: Fowler, R. (ed.), pp. 135-156.

Le Guern, M. (1973), Sémantique de la métaphore et de la métonymie, Paris, Larousse.

Leoni, A.; Pigliasco (eds.) (1979), Retorica e scienze del linguaggio, Roma, Bulzoni.

Lüking, B. (1977), «Rhetorik und Literaturtheorie. Überlegungen zu einer interpretativen Poetik», en: Plett, F. (ed.), pp. 45-61.

Maccoby, N. (1970), «Die neue Wissenschaftliche Rhetorik», en: Schramm, W. (ed.), pp. 55-70.

Martin, J. (1974), Antike Rhetorik. Technik und Methode, München, Beck.

Mazzeo, J. A. (1933), «Metaphysical poetry and the poetic of correspondance", en: Journal of the History of ldeas, 2, pp. 221-246.

Monge, F. (1966), «Culteranismo y conceptismo a la luz de Gracián», en: Estudios... Instituto de Estudios Hispánicos de Utrecht.

Mosconi (y otros) (1981), Discorso e retorica, Torino, Loescher. 
Murphy, J. J. (1974), Rhetoric in the Middle Ages, Berkeley, California University Press.

Naes, A. (1975), Kommunikation und Argumentation, Kronberg, Skriptor.

Owen, G. (ed.) (1968), Aristotle on Dialectic. The topics, Oxford, Clarendon Press.

Perelman, C.; Olbrechts - Tyteca, L. (1958), Traité de l'argumentation, Paris.

Petöfi, J. S. (1973), “Towards an Empirically Motivated Grammatical Theory of Verbal Texts», en: Petöfi, J. S.; Rieser, H. (eds.), pp. 205-275.

- (1975), Vers une théorie partielle du texte, Papiere zur Textlinguistik, Hamburg, Buske.

- (1975a), «Beyond the sentence, between Linguistics and Logic», en: Style in Text, Stokholm, Skriptor.

- (ed.) (1979), Text vs. Sentence. Basic questions of Text Linguistics, Hamburg, Buske (2 vols.).

- García Berrio, A. (1979), Lingüistica del texto y critica literaria, Madrid, Comunicación.

Petöfi, J. S.; Rieser, H. (eds.) (1973), Studies in Text Grammar, Dordrecht, Riedel.

Pierrot, J. (1963), L'imaginaire décadent, Paris, PUF.

Plett, F. (1971), Rhetorische Textanalyse, Hamburg, Buske.

- (1977), "Die Rhetorik der Figuren. Zur Systematiker, Pragmatik und Ästhetik der Elocutio", en: Plett, F. (ed.), pp. 125-166.

- (ed.) (1977), Rhetorik. Kritische Positionen zum Stand der Forschung, München, Fink.

Pratt, M. L. (1977), Toward a Speech Act Theory of Literary Discourse, Bloomington, Indiana University Press.

Raimondi, E. (1978), «Poesia della Retorica», en: Rittẹr Santini, L.; Raimondi, E. (eds.), pp. 123-150.

Rastier, F. (1972), "Systématique des isotopies», en: Greimas, A. J. (y otros), pp. 80-105.

Richards, I. A. (1965), The Philosophy of Rhetoric, New York, Oxford University Press.

Ritter Santini, L.; Raimondi, E. (eds.) (1978), Retorica e Critica letteraria, Bologna, II Mulino.

Rostagni, A. (1930), Arte Poetica di Orazio (Introduzione e Commento), Turín, Chiantore.

Schramm, W. (ed.) (1970), Grundfragen der Kommunikationswissenschaft, Munich.

Searle, J. R. (1969), Speech Acts, London, Cambridge University Press. 
Sebeok, T. (ed.) (1960), Style in Language, London, J. Wiley. Segre, C. (1970), Critica bajo control, Barcelona, Planeta.

- (1978), «Divagazioni su mimesis e menzogna», en: Ritter Santini, L.; Raimondi, E. (eds.), pp. 179-185.

Schiaffini, A. (1962), «Rivalutazione della Retorica», en: Zeitschrift für romanische Philologie, 78, pp. 503-518.

Schmidt, S. J. (1979), Grundiss der empirischen Literaturwissenschaft (vol. 1), Brauschweig, F. Vieweg.

Sontag, S. (1969), Contra la interpretación, Barcelona, Seix-Barral.

Spillner, B. (1974), Lingüistica y Literatura (vers. esp., 1979), Madrid, Gredos.

- (1977), «Das Interesse der Linguistik an der Rhetorik», en: Plett, F. (ed.), pp. 93-108.

Spingarn, J. E. (1908), A History of Literary Criticism in the Italian Renaissance, New York, Columbia University Press (reimpr. 1963).

Todorov, Tz. (1967), Littérature et signification, Paris, Larousse.

- (1968), Poétique. Qu'est-ce que l'estructuralisme?, Paris, Seuil.

Ueding, G. (1976), Einführung in die Rhetorik, Stuttgart, Metzler.

Valesio, P. (1980), Novantiqua. Rhetorics as a Contemporary Theory, Bloomington, Indiana University Press.

Varios autores (1976), «Poetica e Stile», en: Quaderni del Circolo FiloLinguistico Padovano, 8.

- (1980), "Simbolo, metafora, allegoria», en: Quaderni del Circolo Filo-Linguistico Padovano, 11.

Vasoli, C. (1968), La Dialettica e la Retorica dell'Umanesimo, Milano, Feltrinelli.

Vera Luján, A. (1977), Análisis semiológico de "Muertes de perro» de F. Ayala, Madrid, Cupsa.

Warning, R. (ed.) (1975), Rezeptionsästhetik. Theorie und Praxis, München, Fink.

Weinberg, B. (1961), A History of the Literary Criticism in the Italian Renaissance, Chicago University Press.

- (1970-73), Trattati di Poetica e Retorica del '500, Bari, Laterza.

Weinrich, H. (1971), Literatur für Leser, Stuttgart, Kohlhammer.

Woods, M. J. (1968), "Gracián, Pellegrini and the theory of topics", en: The Modern Language Review, LXIII, pp. 854-863.

Zumthor, P. (1971), "Rhétorique médiévale et Poétique", en: Poetics, 1, pp. $46-82$.

- (1972), Essai de Poétique médiévale, Paris, Seuil.

- (1975), Langue, texte, énigme, Paris, Seuil.

- (1978), La masque et la lumière. La poétique des grands rhétoriqueurs, Paris, Seuil. 